\title{
دوافع استخدام كبار السن للفيس بوك والاشباعات المتحققة
}

د. أحمد عبد الستار حسين

رئاسة جامعة ديالى

\section{المستخلص}

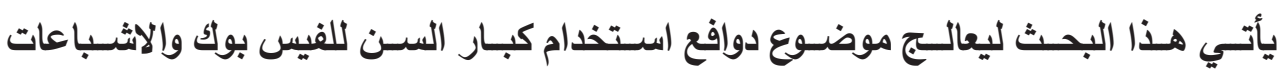

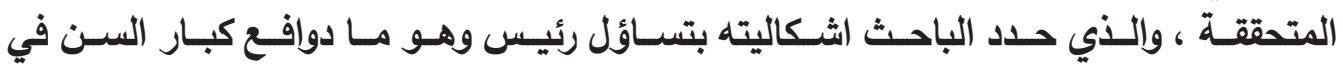

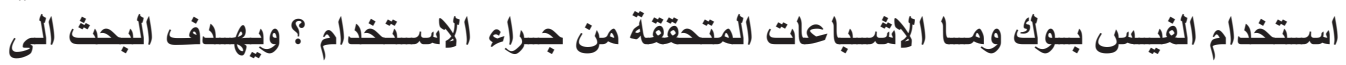

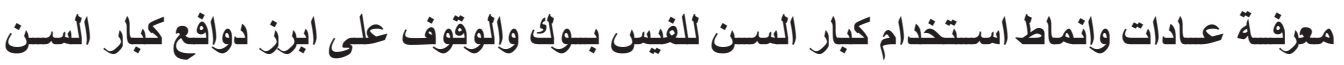

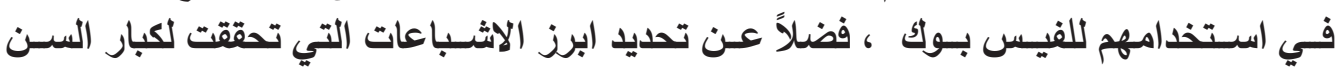

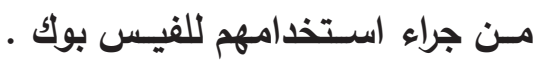

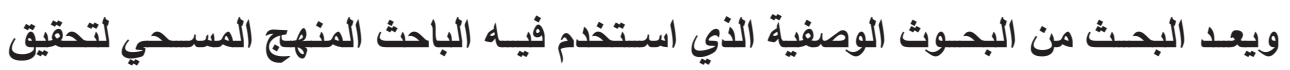

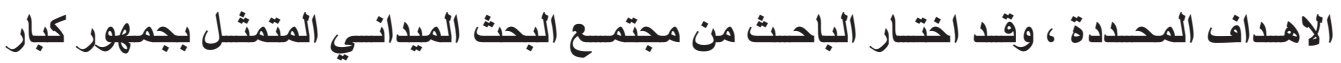

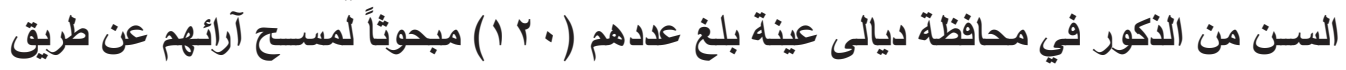

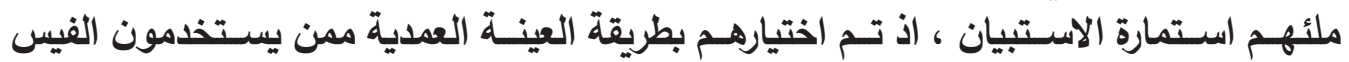

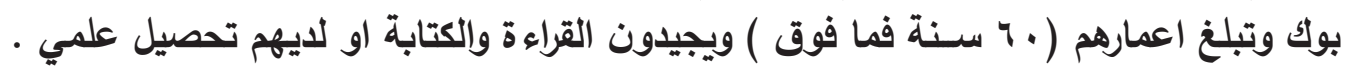

\section{وقد توصل الباحث الى عدد من النتائج اهمها}

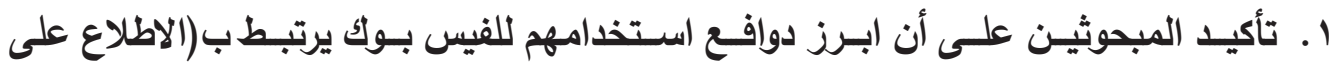

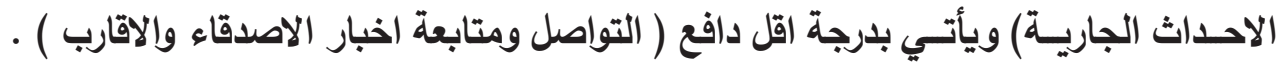

r. اتفق المبحوثون على أن ابرز الاثباعات المتحققة بفعل استخدامهم للفيس بوك هو (جعلهم مطلعيـن على مـا يدور من احداث ) وحقى لهم ( جواً تواصليـاً مع الاصدقاء والاقارب ) ) .

\begin{tabular}{|c|c|}
\hline & مجلة الباحث الاعلامي \\
\hline r & العدد ( هץ ) \\
\hline
\end{tabular}


The Motivations of Using Facebook by Old People and their

\author{
Achieved Need \\ assistant teacher / Ahmed Abdel Sattar Hussein \\ The presidency of the University of Diyala
}

\begin{abstract}
This research deals with the motives of the use of Facebook by elderly people and the achieved needs, which leads the researcher to ask an important question: why an old persons use Facebook and are the achieved needs through which they got? The research aims to find out the habits and patterns of using Facebook by old men and stands on the main motives of the elderly in their use of Facebook. It also identifies the most prominent needs that have been made for the elderly as a result of their use of Facebook.
\end{abstract}

The research is a descriptive one in which the researcher uses survey method to achieve the desired goals. The researcher has chosen a group of old men from Diyala province. The total sample number is about 120 people to clear their views through the questionnaire. The researcher has selected those who are using Facebook and their age is 60 years and above. They can read and write and having a scientific certification.

The researcher has reached to the following results:

1 - The respondents confirm that the main motive of their use of Facebook is linked to the aim of knowing current events, and then comes the goal of communicating and following-up news of friends and relatives.

2. Respondents agreed that the most prominent achieved needs by the use of Facebook are: it makes them familiar with what is going on in the world around them and it helps them to create a communicative atmosphere with their friends and relatives.

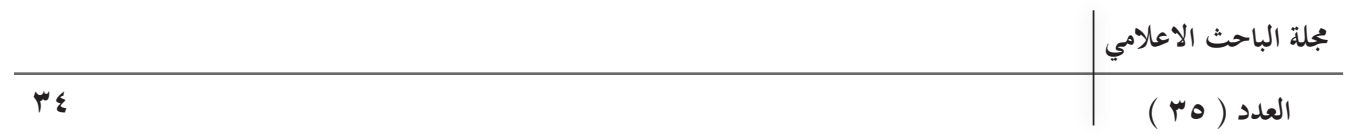




\section{مقدمة}

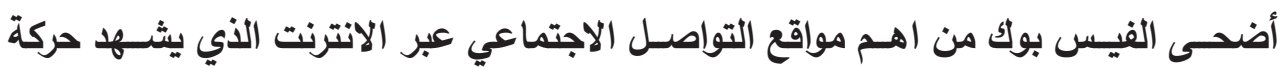

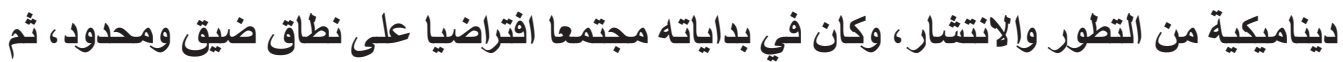

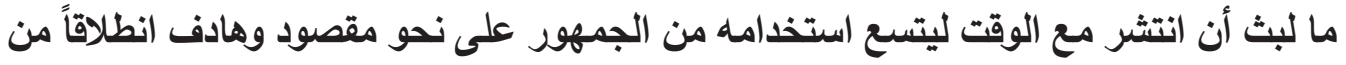
حاجاتهم ودوافعهم لغرض تحقيق اشباعات قد تكون غير متاحة عبر وسائل الإعلام التقليدية.

وسـاعدت الأدوات المتنوعة في موقع الفيس بوك على توفير خدمات تفاعلية متعددة تعمل

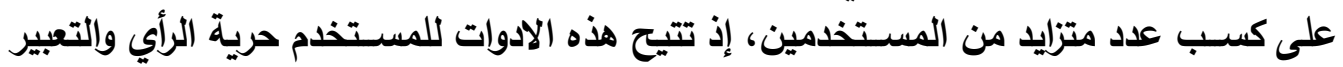

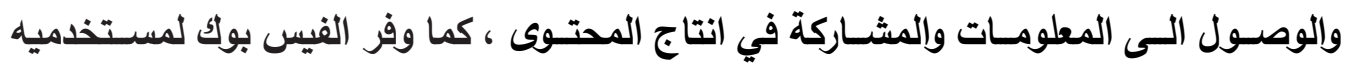

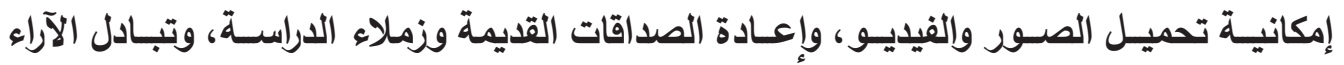
والأفكار والملفات فضلا عن استفادة بعض منهم في أعمالهم وتجارتهم ومصالحهم الخاصة .

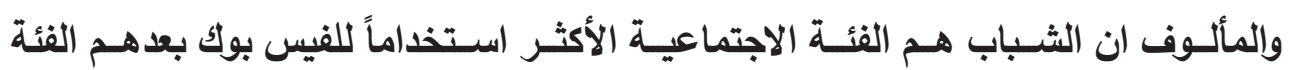

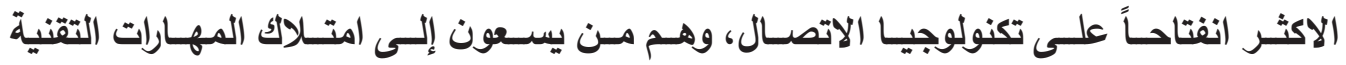
واستخدامها لكونها تسمح لهم بالتعبير عن هويتهم والابتعاد تدريجياً عن مراقبة أولياء أمرهم .

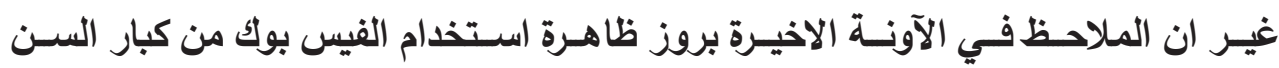

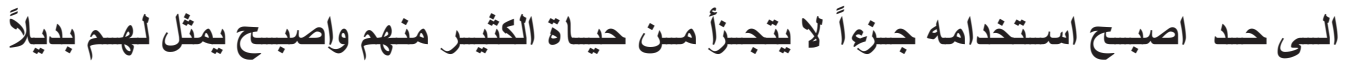

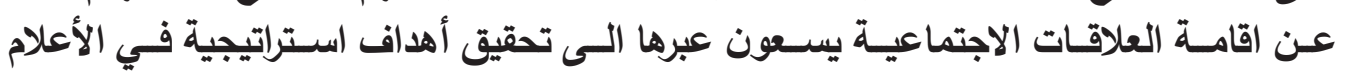

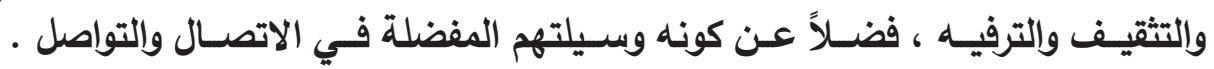

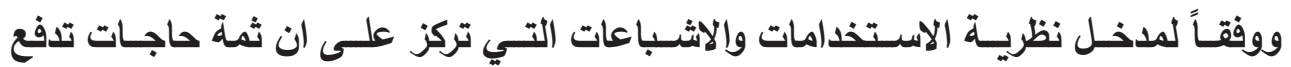

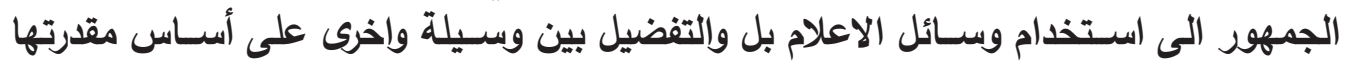

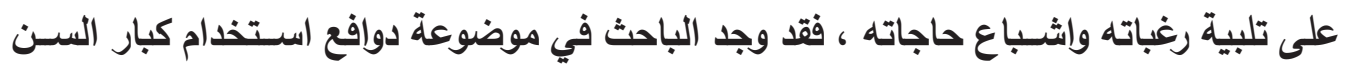

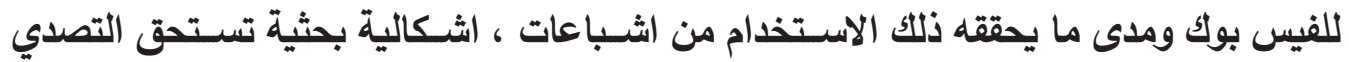

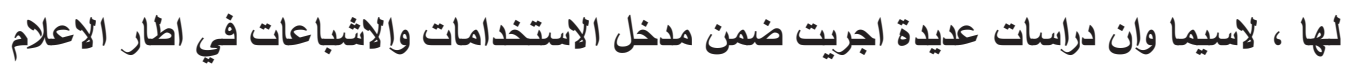

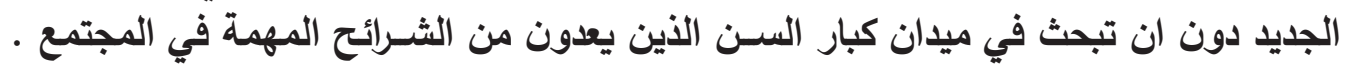

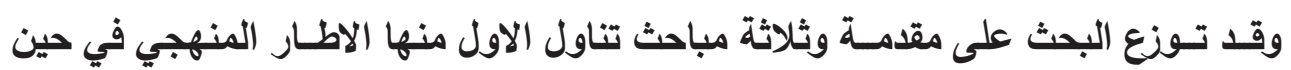

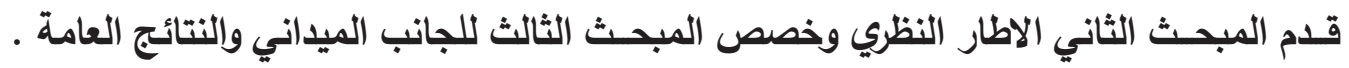




\section{الاطار المنهجي اولاً : مشكلة البحث}

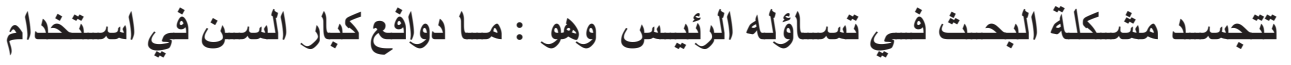

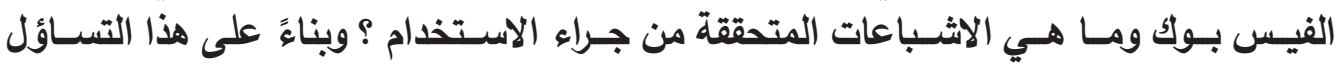

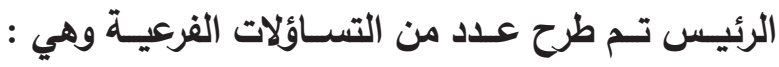
1 - ما عادات وإنماط استخدام كبار السن للفيس بوك ؟ r - ما ابرز دوافع استخدام كبار السن للفيس بوك ؟ r- ما ابرز الاشباعات التي تحققت لكبار السن من جراء استخدامهم للفيس بوك ؟ ثانياً : اهمية البحث يجمل الباحث اهمية البحث من الناحية الاكاديمية والميدانية بما يأتي : 1 - يفتـح البحـث (فاقـاً بحثية جديدة بثـأن دوافع اسـتخدام مواقع التواصل الاجتماعي بثـكل

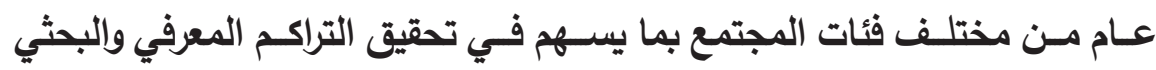
ب - إثراء المكتبات الاعلامية بدراسـات في ميدان مواقع التواصل الاجتماعي ، لا سـيما وإنها تعد من الظواهر الاعلامية الجديدة نسـبياً.

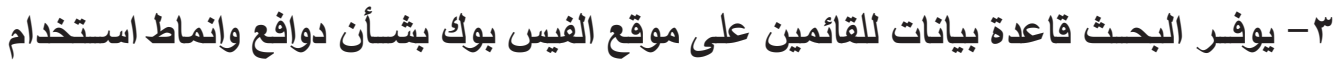

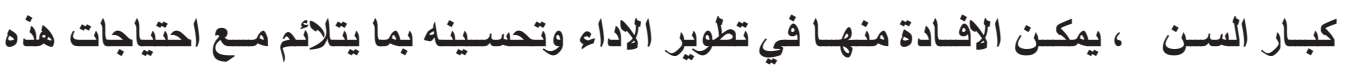

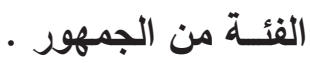

\section{ثالثاً : اهداف البحث}

يسعى البحث الى تحقيق عدد من الاهداف وهي :

1 - كثف عادات وانماط استخدام كبار السن للفيس بوك

r - معرفة ابرز دوافع استخدام كبار السن للفيس بوك

r- تحديد ابرز الاشباعات التي تحققت لكبار السن من جراء استخدامهم للفيس بوك .

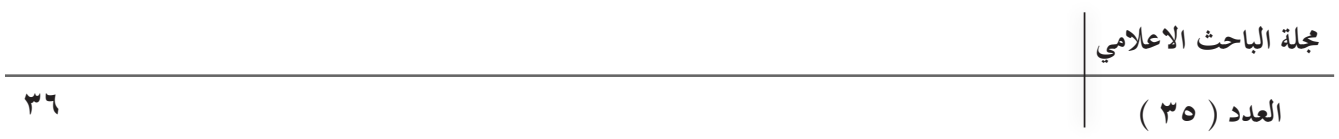




\section{رابعاً : نوع البحث ومنهجه}

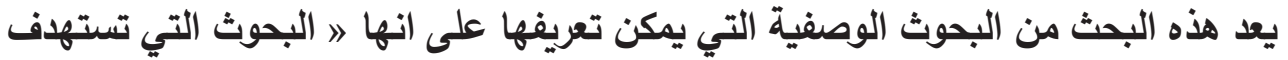

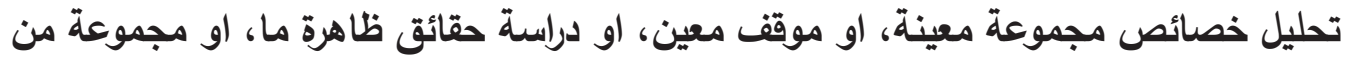

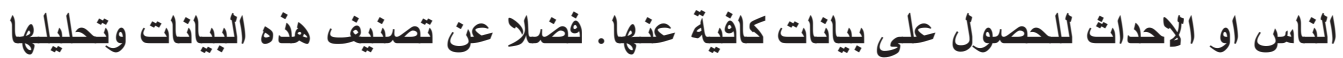

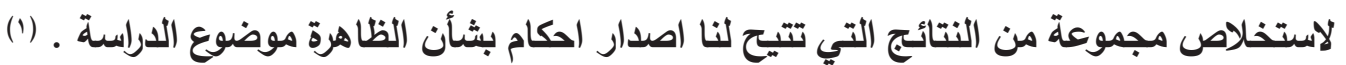

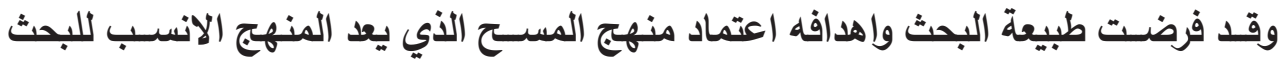

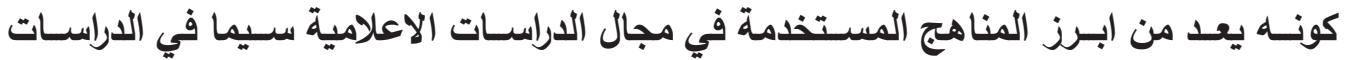
الوصفية والاستكشافية.

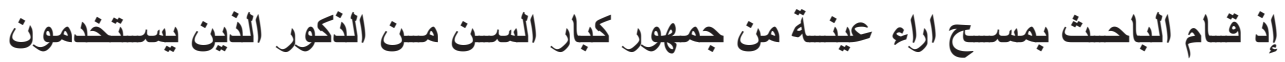

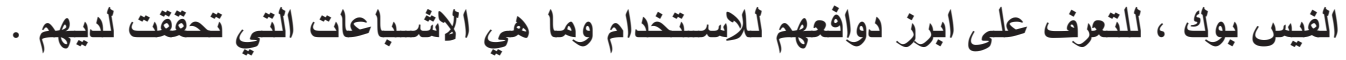
خامساً : مجالات البحث وحدوده

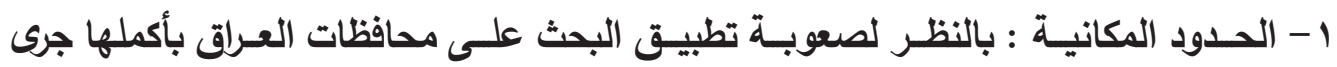

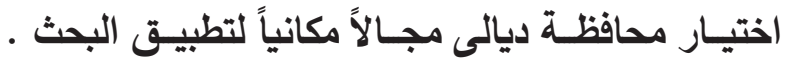

Y - الحـدود البثـرية : تمثلـت الحدود البثـرية للبحث بجمهور كبار السـن مـن الذكور الذين

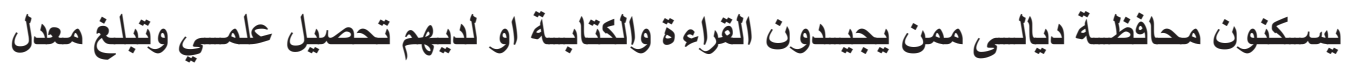

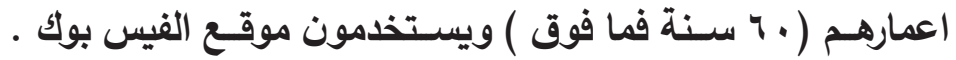

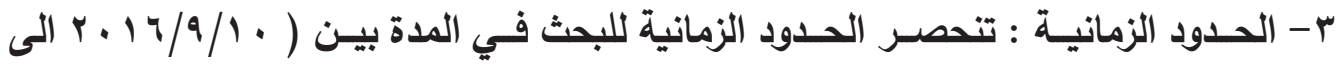

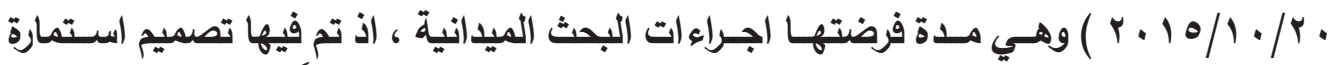

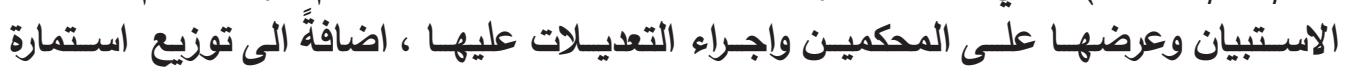

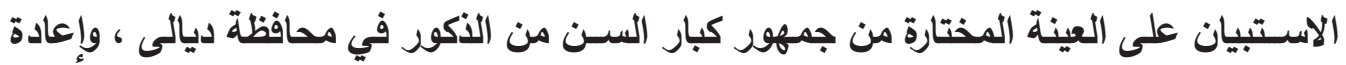

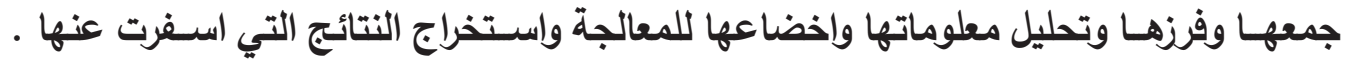

\section{سادساً : مجتمع البحث وعينته}

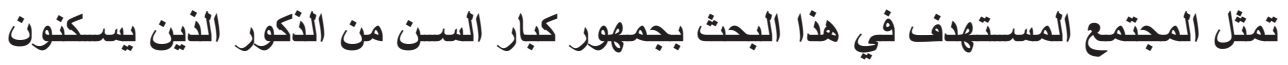

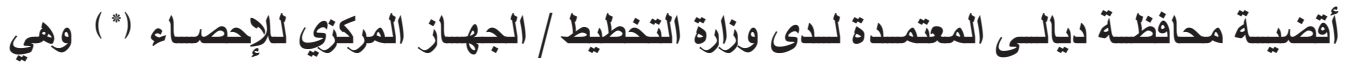
(بعقوبـة ، المقداديـة ، الخالـص ، خانقيسن ، بلدروز ، كفري ) ) .

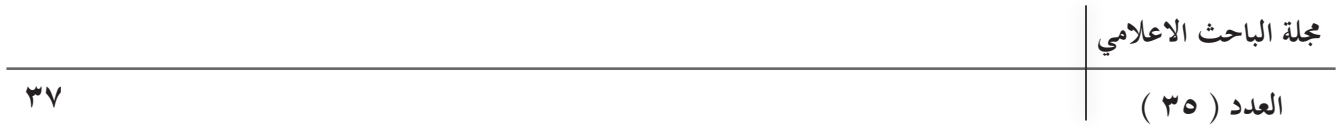




\section{وقد جاء اختيار الباحث للذكور من كبار السن للأسباب الاتية}

1. امكانية الوصول اليهم كونهم من مرتادي الاماكن العامة (عينة متاحة ) r . مـن خـلال ملاحظـة الباحث وجد ان ظاهرة اسـتخدام الفيس بوك تتجســ في كبير السـن

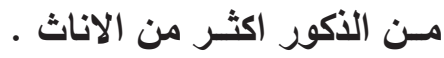

\section{اما عينة البحث فقد جرى اختيارها على مرحلتين وكما يأتي}

المرحلـة الاولـى : تمثلــت بالإفـادة من تقــيمات محافظــة ديالى الـى اقضية واعتمــاد العينة

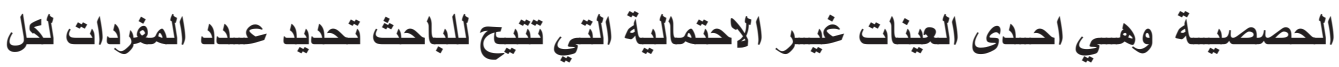

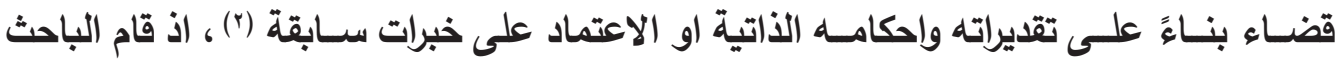

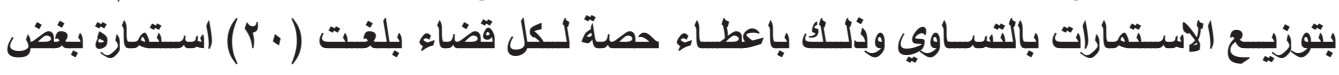

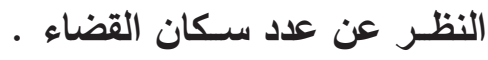

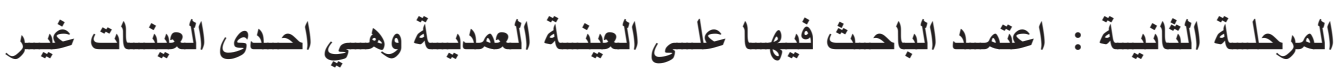

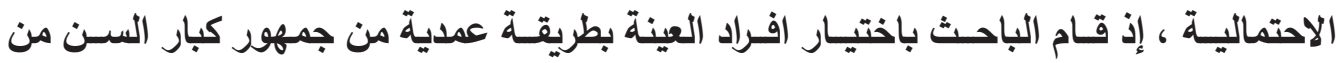

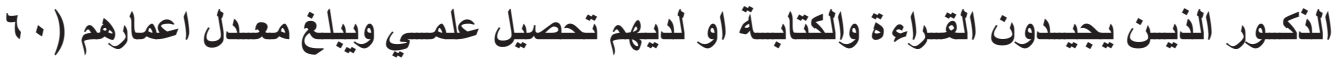

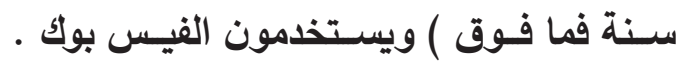

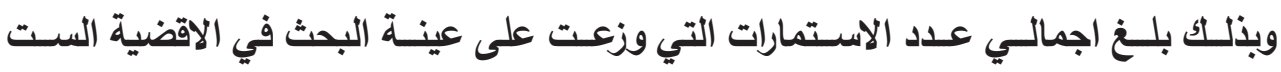

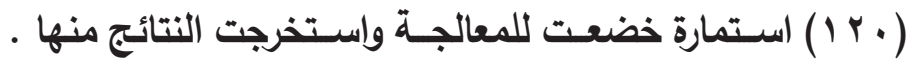
سابعاً : ادوات البحث في اطــار الاهداف التي يسـعى البحـث الى تحقيقها، اقتضت الضرورة اســـــام اسـتمارة

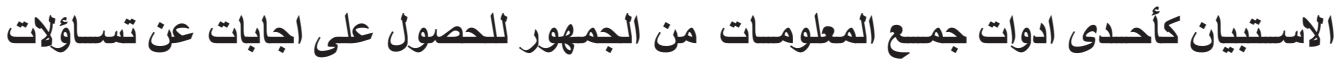

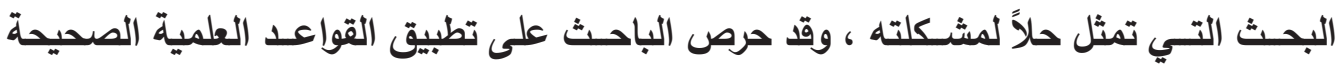

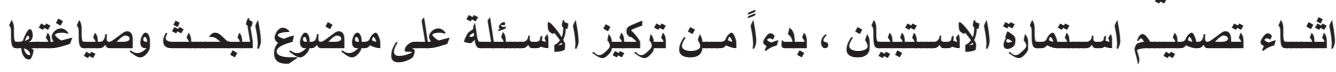

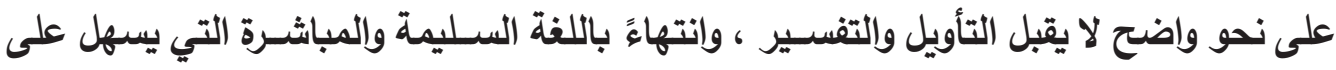

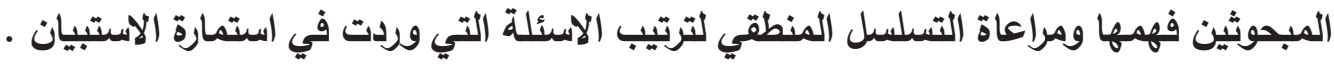
واعتمـــ الباحـث علـى نمـط الاســـلة ذات النهايـات المغلقـة ، وهـي الاســـلة المقرونـة 


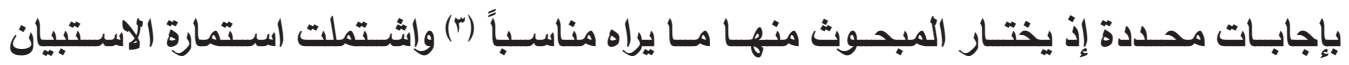

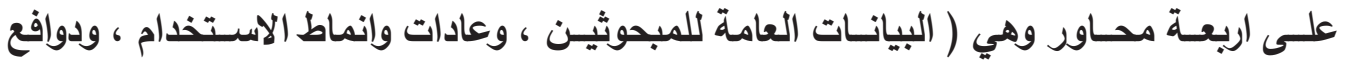

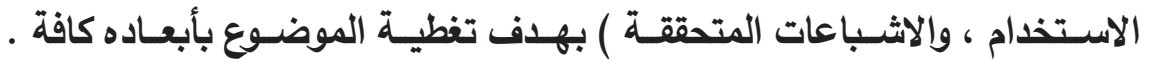

\section{ثامناً : اختبار الصدق والثبات}

\section{|- |- |- الصدق}

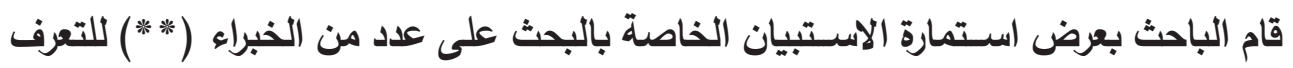

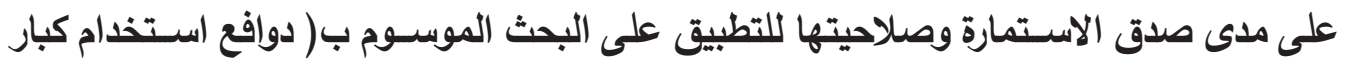

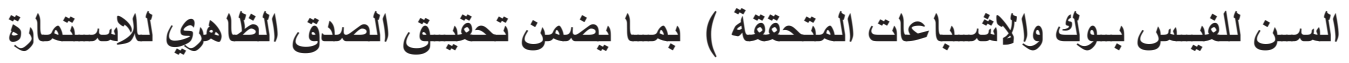

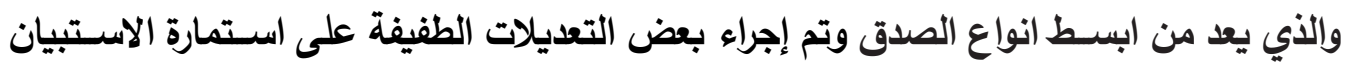

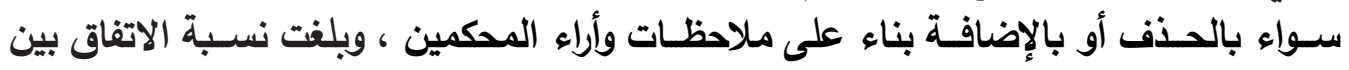

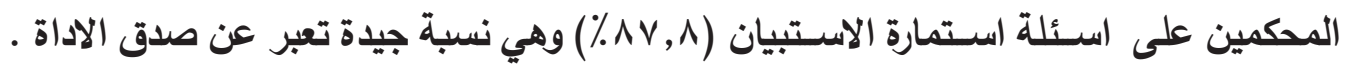
إذ تم احتساب الصدق الظاهري على وفق المعادلة الآتية :

الصدق الظاهري = . مجموع الفقرات المتفق عليها من قبل المكين

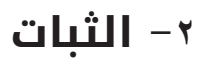

يمكن حسـاب الثبـات بطـرق عـدة وذهـب الباحـث إلـى اختبـار الثبـات بطريقــة اعادة

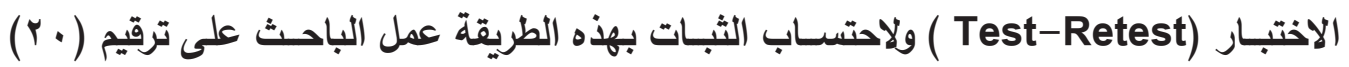

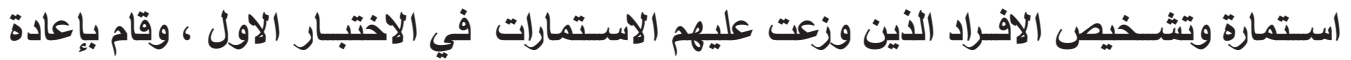

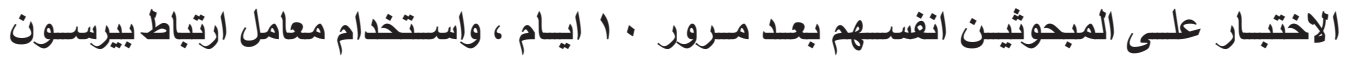

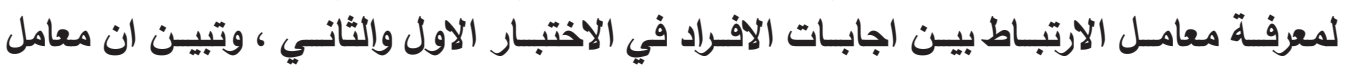

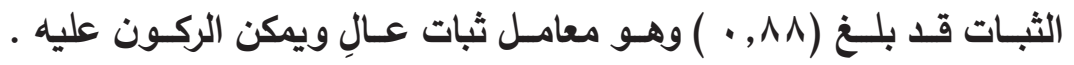

تاسعاً : دراسات سابقة

(؛) دراسة (التميمي)

ســلطت الدراســة الضوء على العلاقة بين اســخدام الثــباب العراقي وســائل الإعلام الجديد

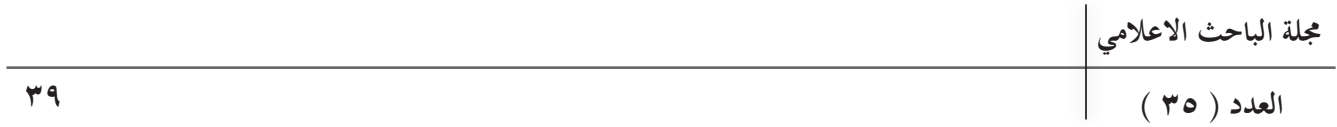




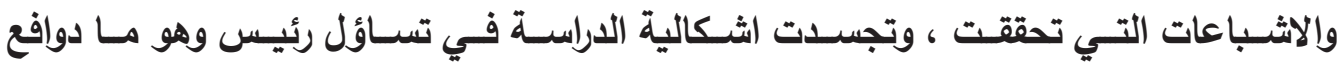

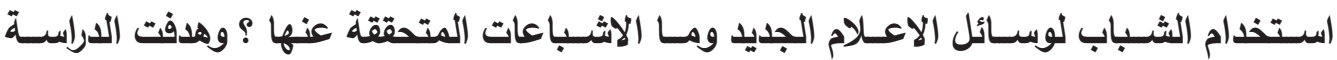

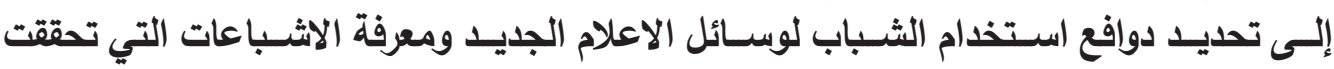
مسن جراء هذا الاسـتخدام .

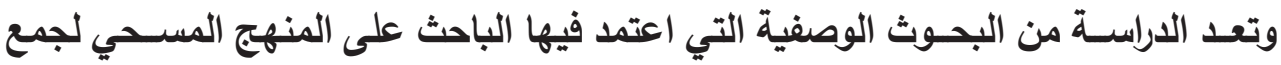

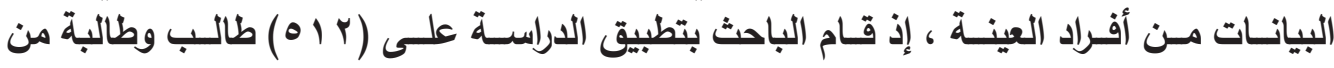
المدارس الاعدادية والجامعات في مدينة بغداد عبر استخدام العينة العشوائية المتعددة المراحل .

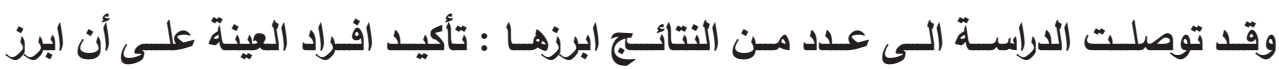

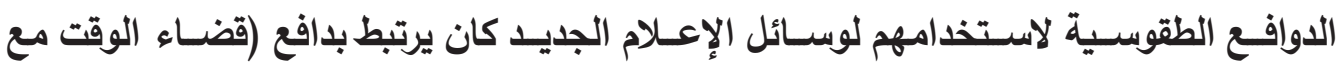

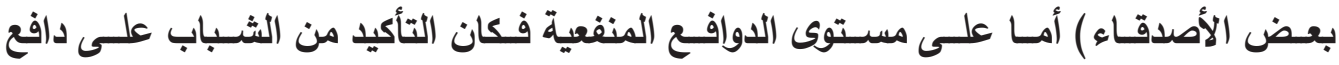

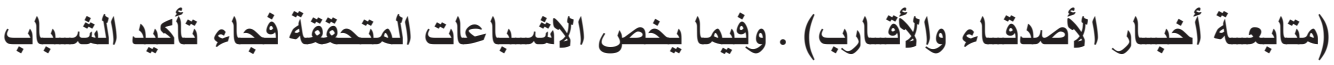

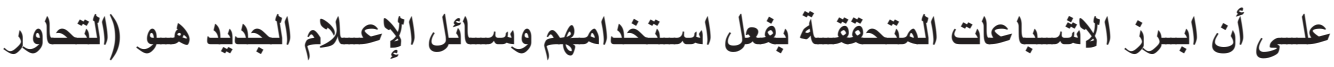

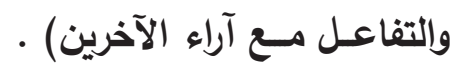

r) براسة (العبيدي)

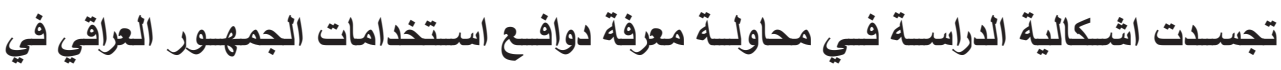

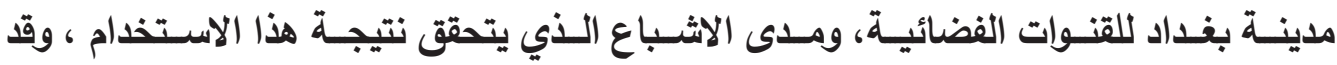

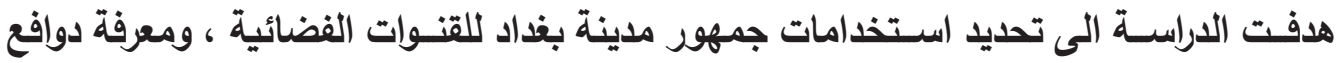

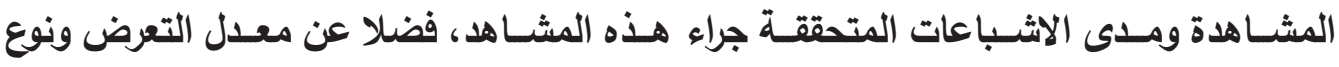

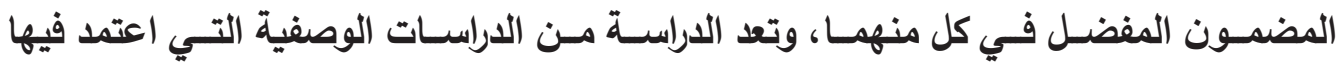

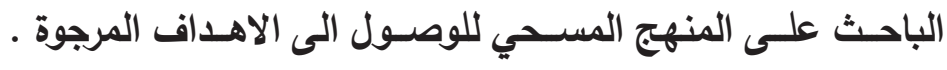

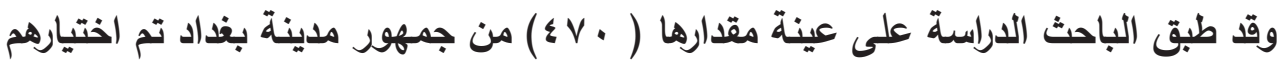

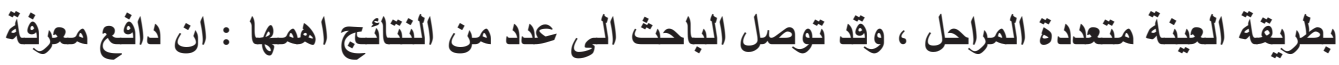

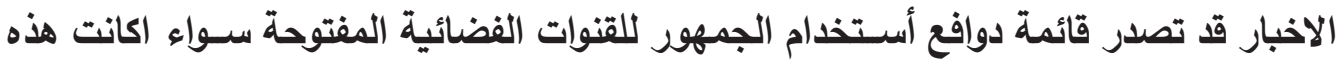

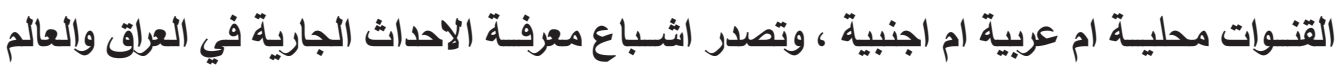

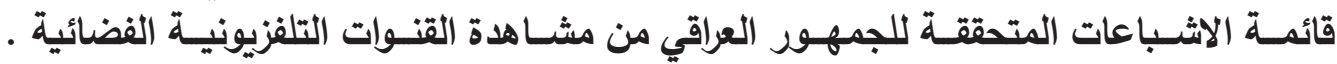

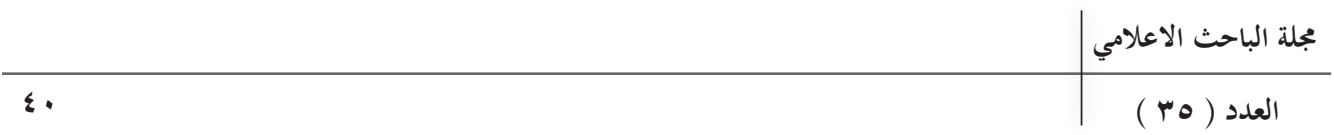




\section{r) (ז) دراسة (علي )}

تنطلـق الدراســة مـن اشـكالية تبحث في مدى حرص كبار السـن على اســـــام التلفزيون

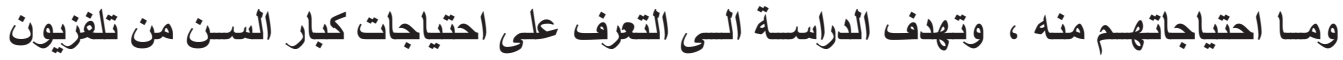

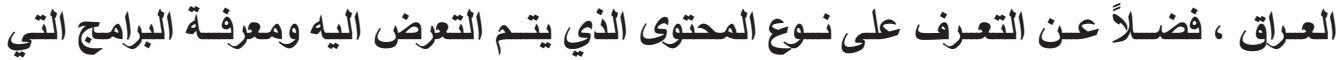

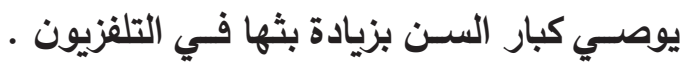

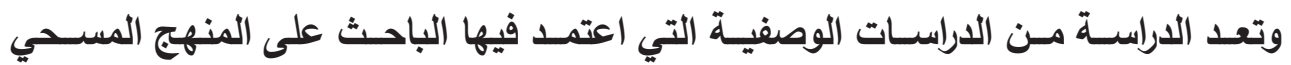

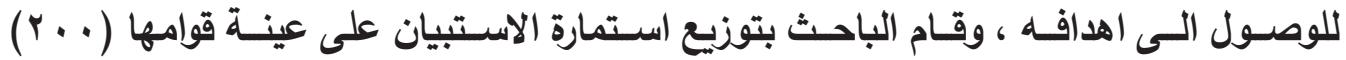

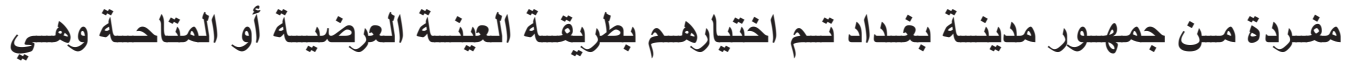

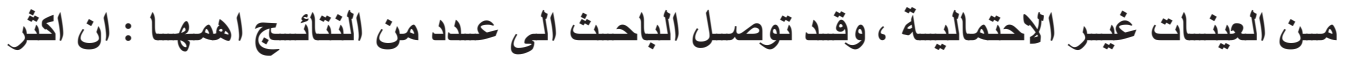

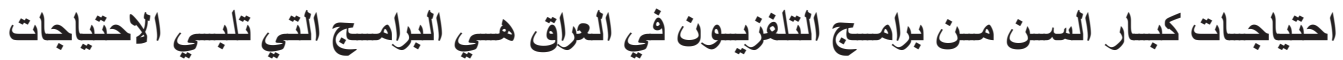

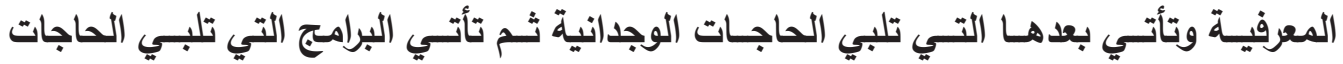

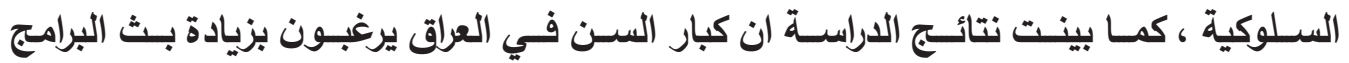

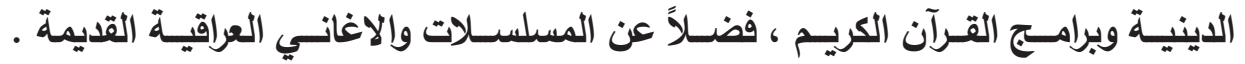

\section{اوجه التشابه والاختلاف مع الدراسات السابقة ومدى الافادة منها}

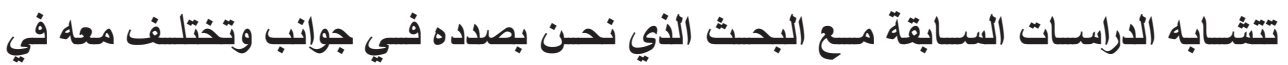

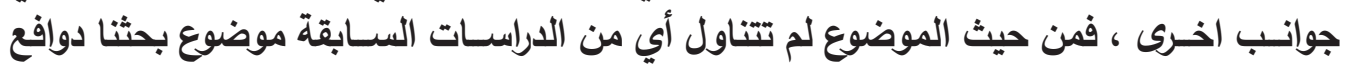

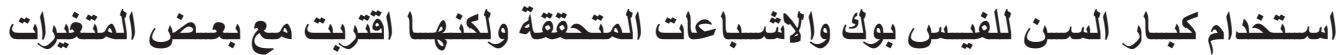

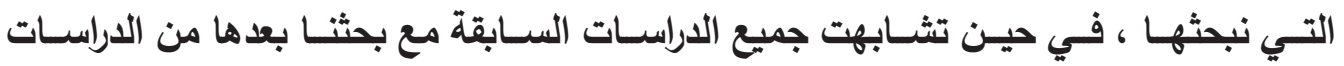

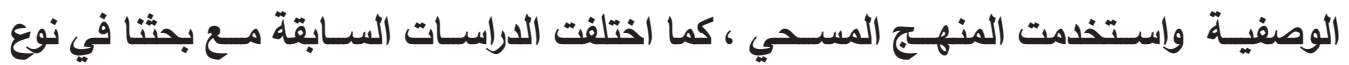

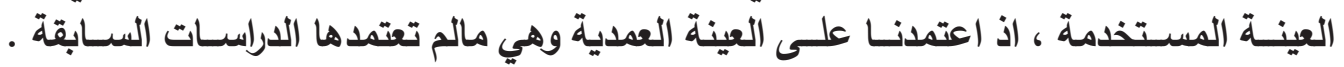

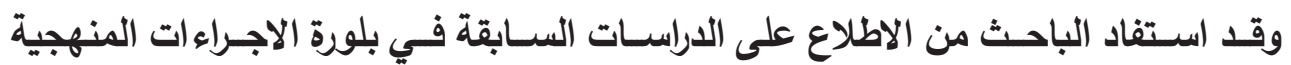

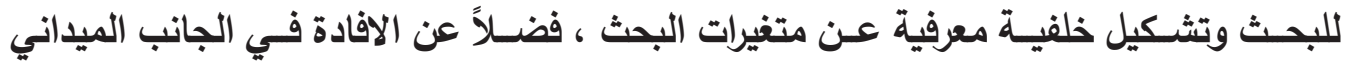

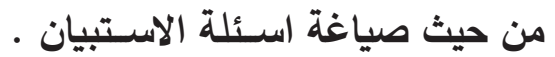
عاشراً : تحديد المصطلحات * الدافع : هو مثير داخلي يدفع الفرد الى القيام بسلوك من اجل اشباع حاجة او تحقيق هدف . 
* الاستخدام : المقصود به استخدام كبار السن للفيس بوك والافادة من مضامينه .

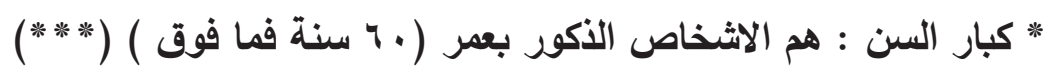
* الاشباع : هو إرضاء رغبة أو بلوغ هدف ما أو خفض دافع معين .

\section{الاطار النظري للبحث}

\section{اولاً : مدخل الاستخدامات والاشباعات}

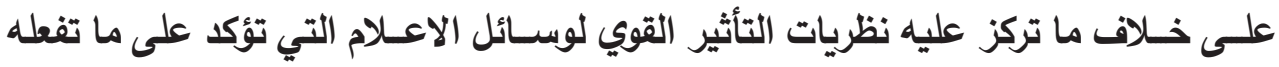

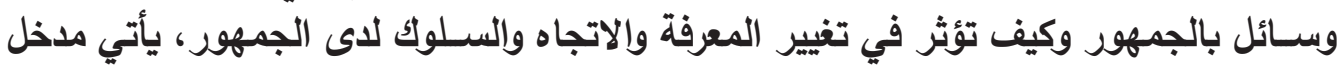

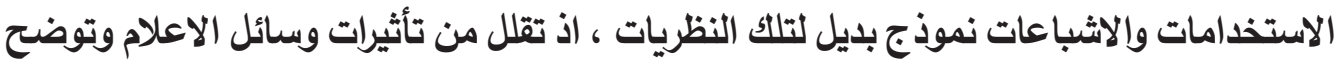

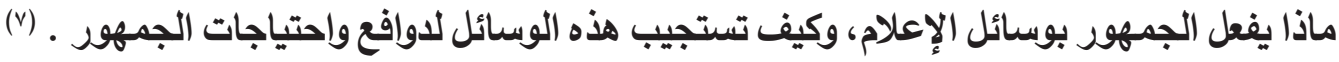
إذ ادى ادراك عواقب الفـروق الفرديـة والتبايـن الاجتماعي على السـلوك المرتبط بوســائل

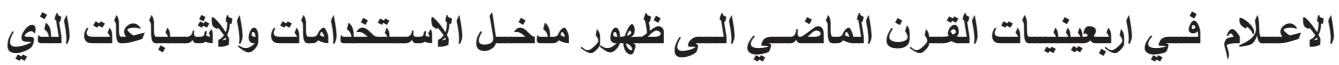

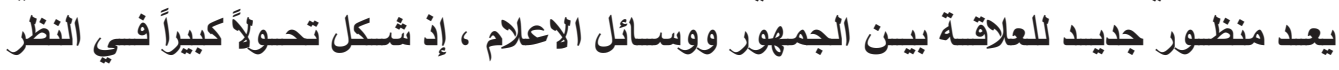

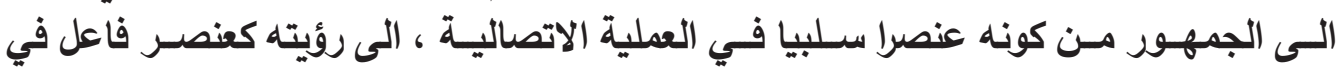

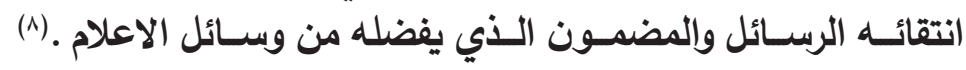

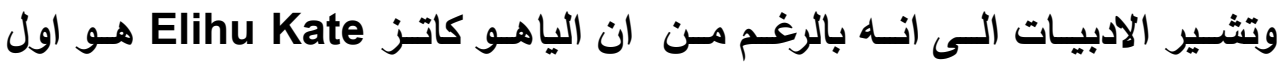

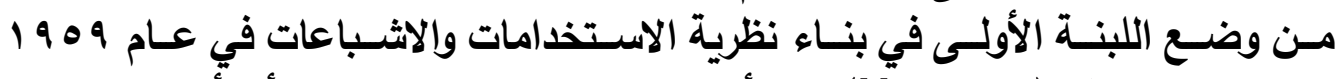

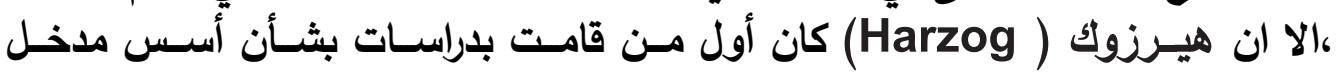

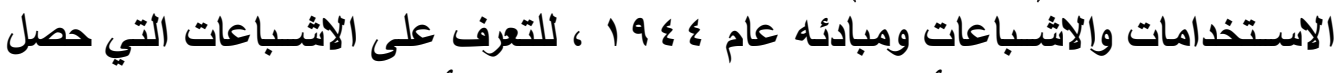

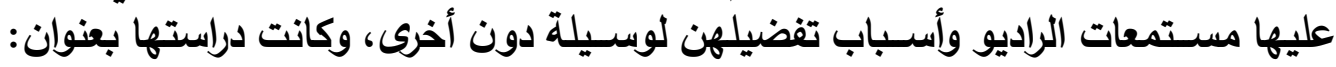

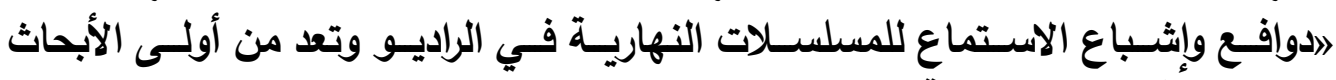

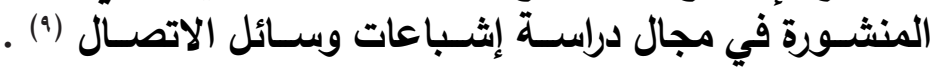

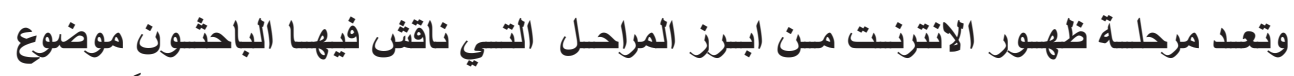

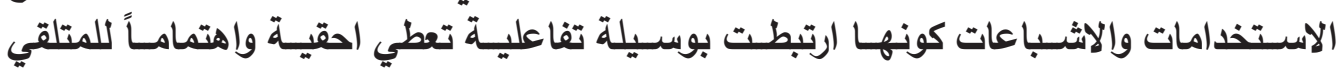

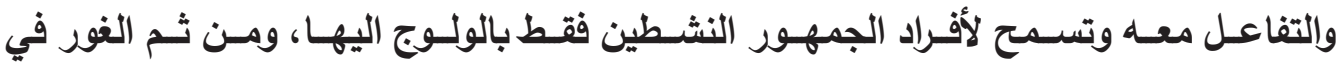


محتوياتهـا ، إذ ضمــت الصحافـة والراديو والتلفزيون وبذلك جمعت وســائل الاتصال الجماهيري

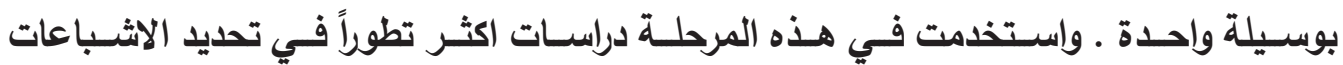

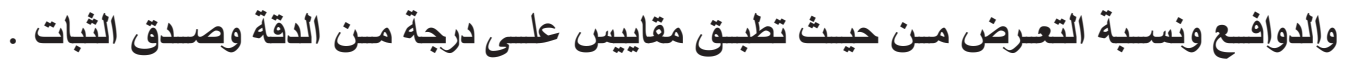
ويـرى الباحثـون ان منظـور الاسـتخدامات والاثـباعات يحقـق ثلاثـة اهداف

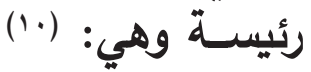

1. السعي الى اكتشاف كيف يستخدم الافراد وسائل الاتصال، وذللك بالنظر الى الجمهور

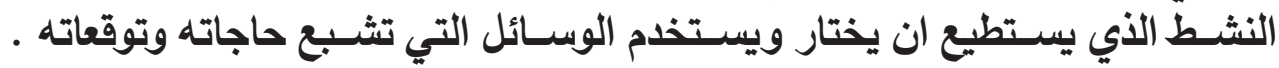
r. . الكثـف عـن دوافـع التعـرض لوسـيلة معينـة من وسـائل الاتصـال والتفاعل

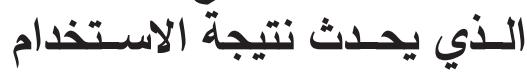

r. التأكيـد علـى نتائـج اسـتخدام وسـائل الاتصــال بهدف فهـم عمليـة الاتصال

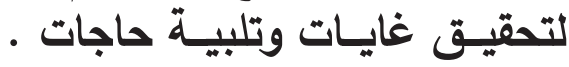

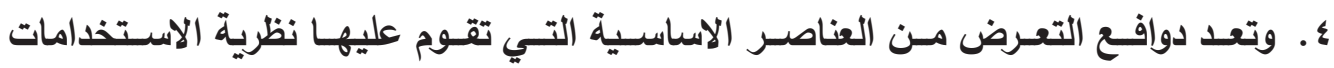

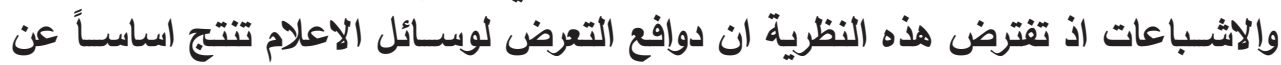

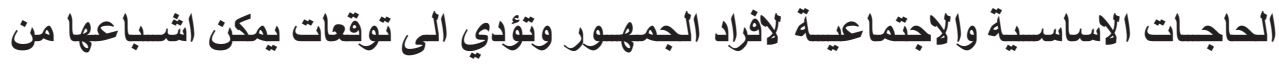

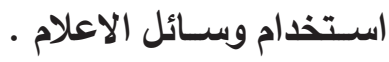

\section{وقسم الباحثون دوافع التعرض الى : (1')} أ. دوافـع نفعيـة : وتتضمـن اسـتخدامات موجهــة لمحتـوى وسـيلة الاعـلام مـن اجـل تحقيق

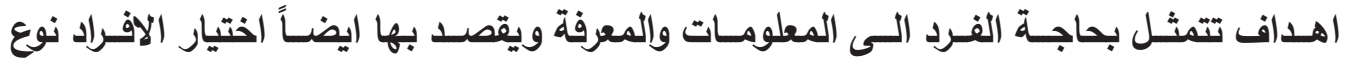

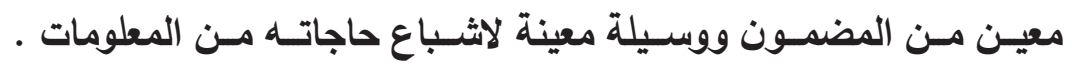

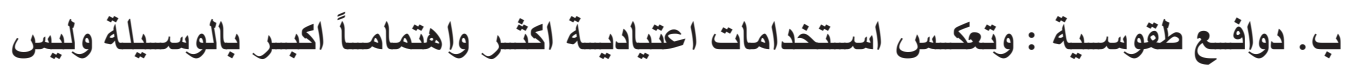

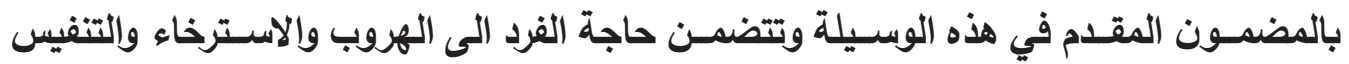

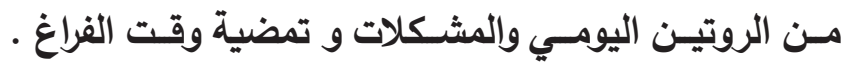

اما الاشباعات المتوقعة من وسائل الاعلام فيصنفها لورانس وينر الى نوعين وهي : (rائ)

\begin{tabular}{l|c} 
& العلة الباحث الاعلامي (ro
\end{tabular}




\section{1- اشباعات المحتوى}

وتنتج عن التعرض لمحتوى وسائل الاعلام وتنقسم الى نوعين : أ. اشباعات توجيهية تتمثل بمراقبة البيئة وإلحصول على المعلومات

ب. اشباعات اجتماعية ويقصد بها ربط (لمعلومات التي يحصل عليها الفرد بشبكة علاقته الاجتماعية

\section{r- اشباعات عملية}

وتنتــج عـن عمليـة الاتصـال والارتبـاط بوسـيلة محـددة ولا ترتبـط مباشـرة بخصائص

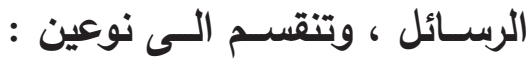

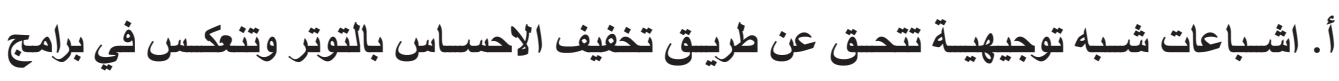
التسـلية والترفيه.

ب. اشباعات شبه اجتماعية وتتحقق عن طريق التوحد مع شخصيات وسائل الاعلام . ثانياً : الفيس بوك وميزة الاستخدام

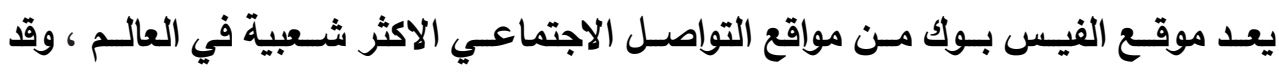

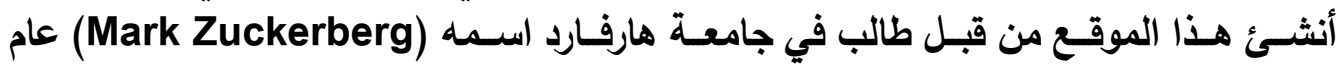

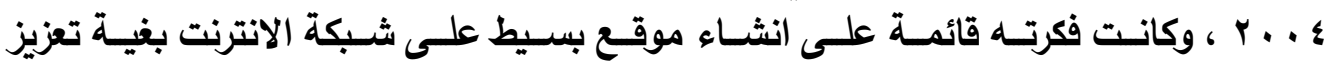

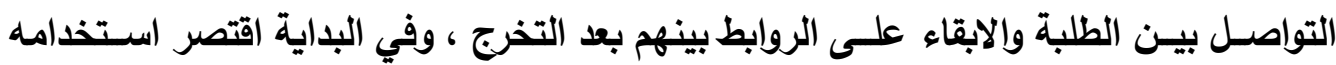

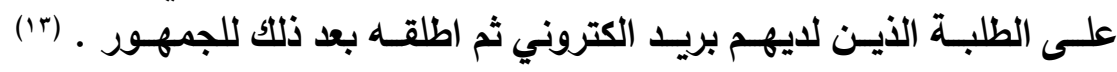

ويسـاعد اسـتخدام الفيس بوك المسـتخدمين على الاتصال مع الآخريـن ، وإقامة علاقات

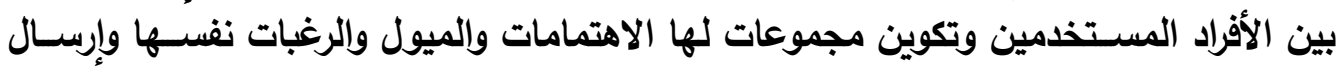

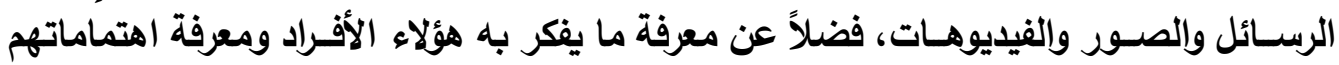

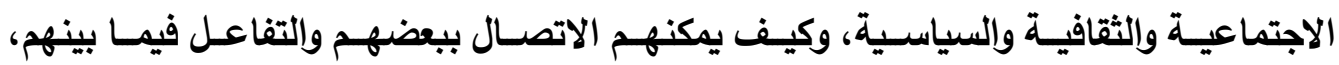

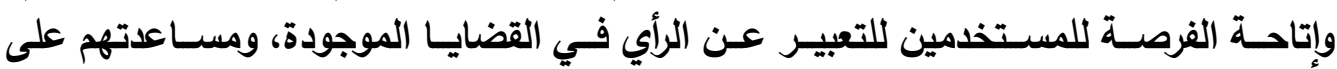

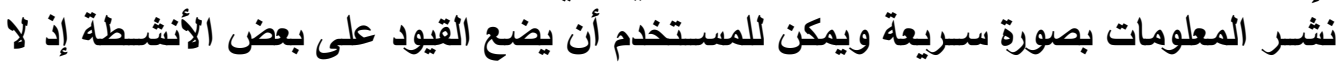

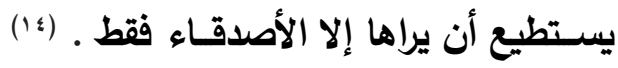

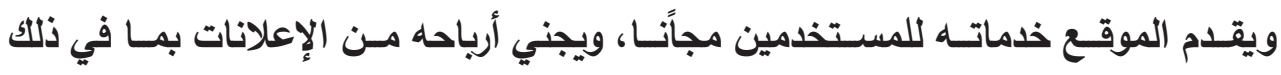




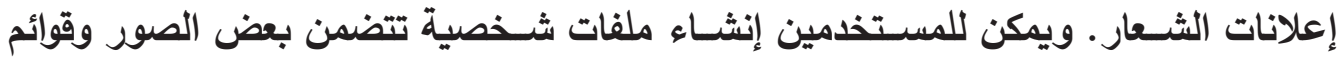

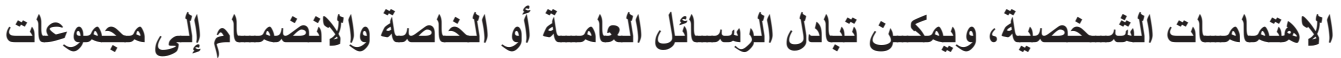

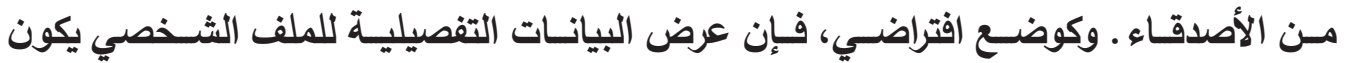

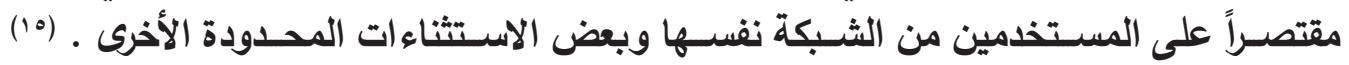

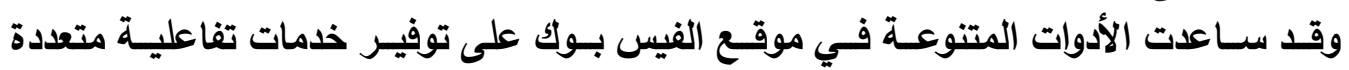
تعـل على كسـب عـدد متزايد من المسـتخدمين .

\section{نتائج الدراسة الميدانية}

\section{المحور الاول : البيانات العامة للمبحوثين}

1- التحصيل الدراسي

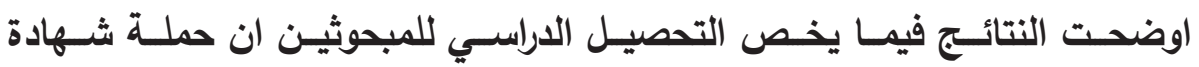

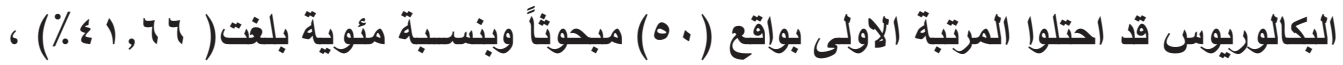

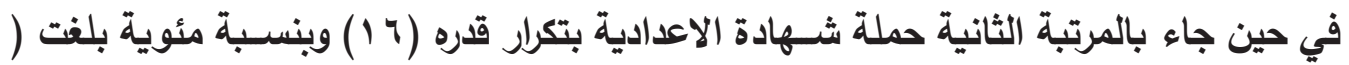

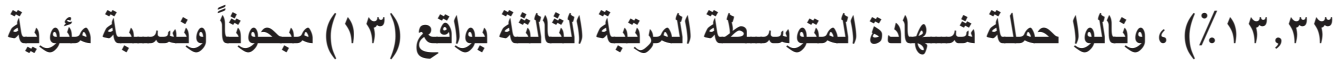

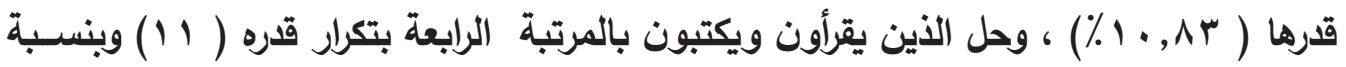

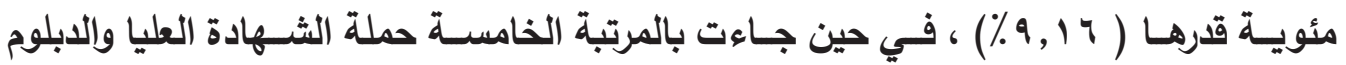

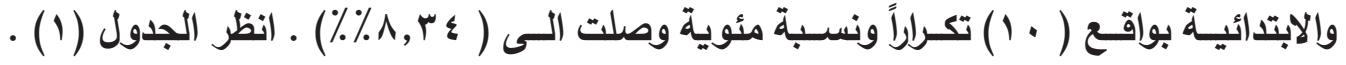
جدول ( ا ) يبيـن توزيع المبحوثين على وفق متغير التحصيل الدراسـي

\begin{tabular}{|c|c|c|}
\hline النسبة المئوية ٪ & التكرار & التحصيل الاراسي \\
\hline \%ะ & 0. & بكالوريوس \\
\hline \% & 19 & اعدادية \\
\hline$\% 1 \cdot \wedge \mu$ & $1 \%$ & متوسطة \\
\hline$\% 9,19$ & 11 & يقرأ ويكتب \\
\hline$\% \wedge, r \varepsilon$ & 1. & شهادة عليا \\
\hline$\% \wedge, \Psi \varepsilon$ & 1. & دبلوم \\
\hline$\%$ & 1. & ابتدائية \\
\hline$\% 1 \ldots$ & ir. & المجموع \\
\hline
\end{tabular}




\section{r- العمل}

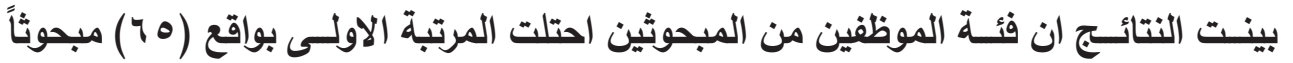

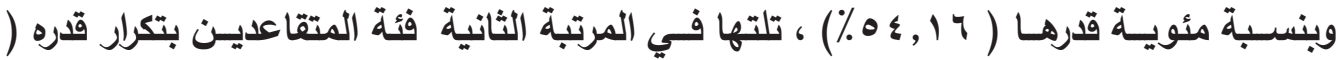

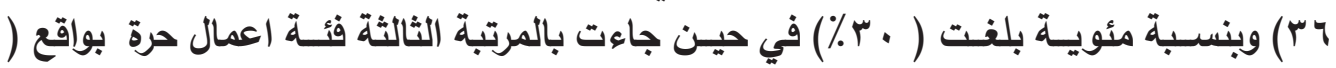

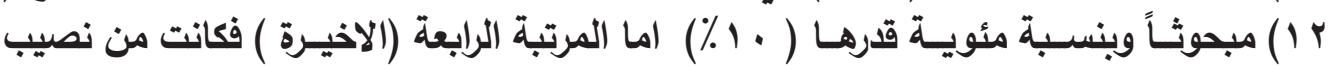

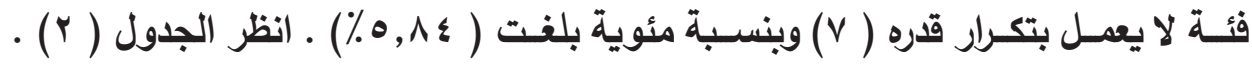
جدول ( r ب يبين ترتيـب المبحوثين على وفق متفير العمل

\begin{tabular}{|c|c|c|}
\hline النسبة المئوية ٪ & التكرار - ار & العمل - العل \\
\hline $0 \leqslant, 17$ & 70 & موظف \\
\hline$\%$. & $r 4$ & متقاعد \\
\hline$\% 1$. & ir & اعمال حرة \\
\hline$\bullet, \wedge \varepsilon$ & $\mathrm{V}$ & لا يعمل \\
\hline$\%$ & Ir. & المجموع \\
\hline
\end{tabular}

\section{r- الحالة الاجتماعية}

كثـفت اجابـات المبحوثيـن بخصوص حالتهم الاجتماعية عن صــارة المرتبة الاولى لفئة

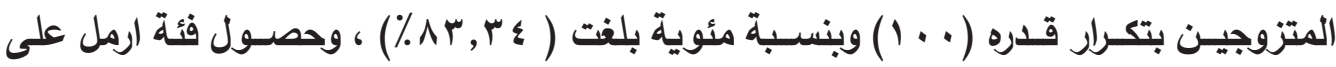

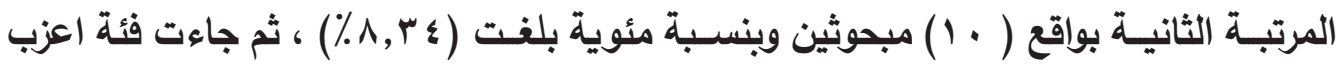

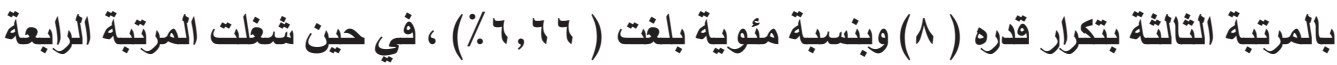

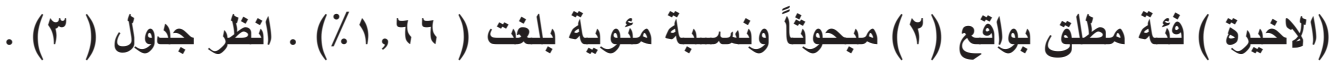

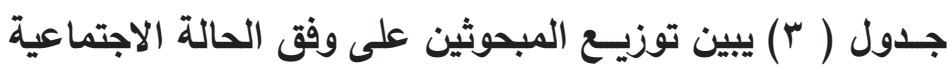

\begin{tabular}{|c|c|c|}
\hline النسبة المئوية \% & التكرار & الحالة الاجتماعية \\
\hline \% & $1 \ldots$ & متزوج \\
\hline$\% \wedge, \Psi \varepsilon$ & 1. & ارمل \\
\hline$\%$ & $\Lambda$ & اعزب \\
\hline$\% 1,74$ & Y & مطلق \\
\hline$\% 1 \ldots$ & $i r$. & المجموع \\
\hline
\end{tabular}

\section{ع - متوسط الدخل الشهري بالدينار}

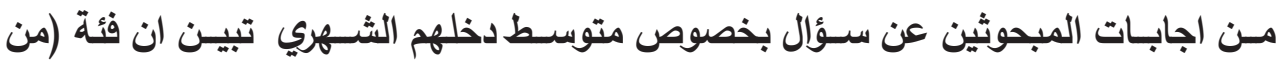

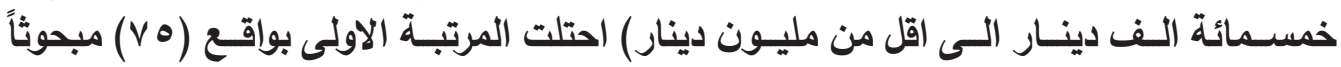




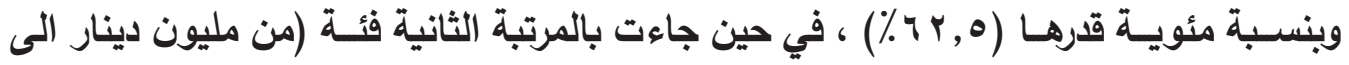

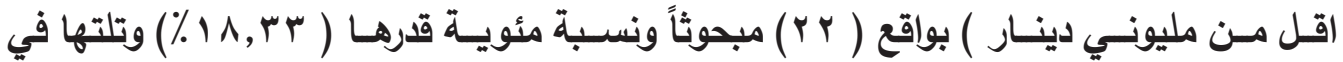

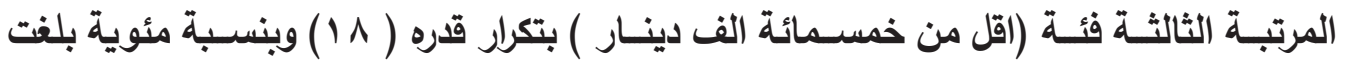
( 0 \%) ، ، وحصلـت فئسة (مليونـي دينار فأكثر ) على المرتبة الرابعة (الاخيـرة ) بتكرار قدره

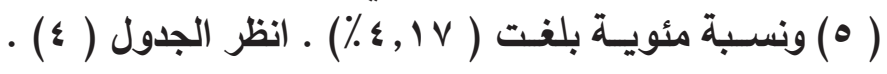

جدول ( ؛ ) يبين ترتيب المبحوثين على وفق متفير متوسـط الاخل الثـهري

\begin{tabular}{|c|c|c|}
\hline النسبة المئوية \% & 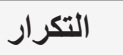 & متوسط الاخل الثهري بالدينار \\
\hline$\% \pi r, 0$ & vo & من خمسمائة الف دينار الى اقل من مليون دينار \\
\hline$\% 1 \wedge, r \mu$ & rY & من مليون دينار الى اقل من مليوني دينار \\
\hline$\% 10$ & 11 & اقل من خمسمائة الف دينار \\
\hline$\%\{, 1 V$ & 0 & مليوني دينار فأكثر \\
\hline$\% 1 \ldots$ & ir. & 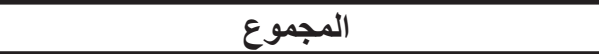 \\
\hline
\end{tabular}

\section{المحور الثاني : عادات وانماط الاستخدام ه- بدء الاستخدام}

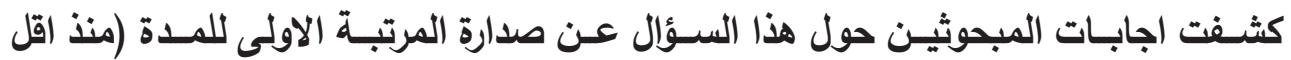

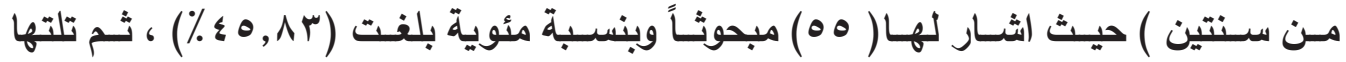

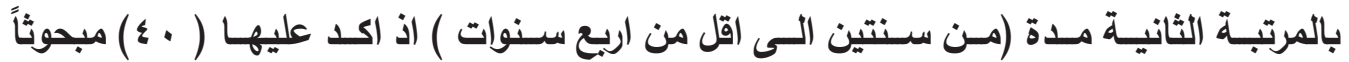

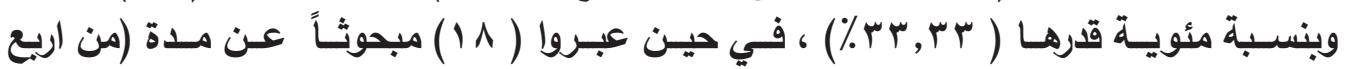

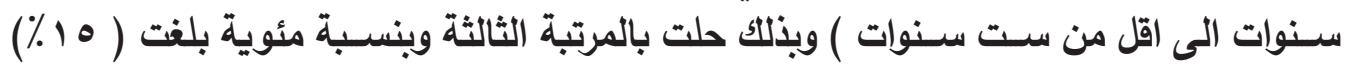

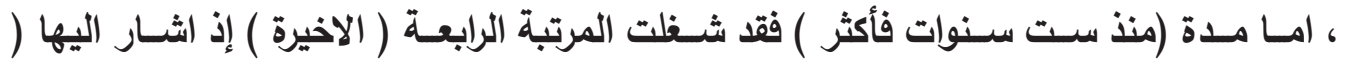

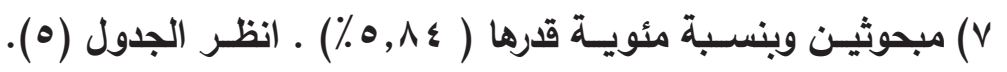

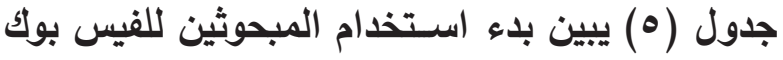

\begin{tabular}{|c|c|c|}
\hline النسبة المئوية \% & التكرار & بلدء الاستخدام \\
\hline$\% \varepsilon \theta, \wedge \mu$ & 00 & منذ اقل من سنتين \\
\hline \%rr,rT & 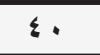 & من سنتين الى اقل من اريع سنوات \\
\hline$\% 10$ & $\overline{11}$ & من اريع سنوات الى اقل من ست سنوات \\
\hline$\%, \wedge \varepsilon \varepsilon$ & $\bar{v}$ & منذ ست سنوات فَاكتُر \\
\hline$\% 1 \ldots$ & $\pi$. & المجموع \\
\hline
\end{tabular}




\section{צ- معدل الاستخدام اليومي}

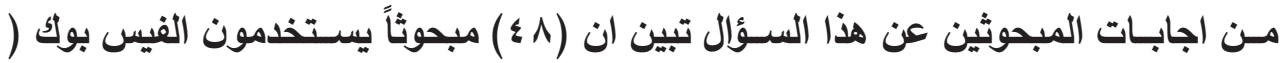

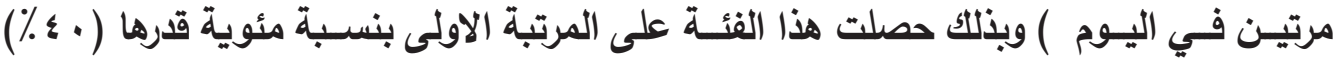

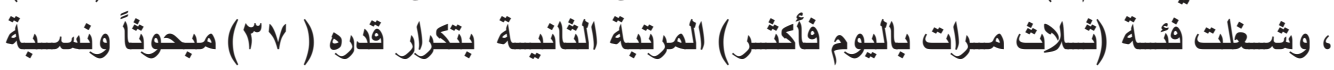

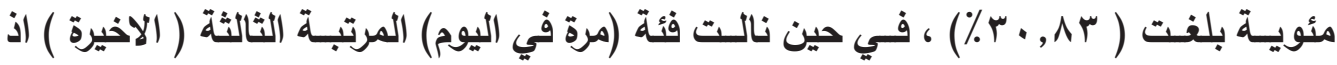

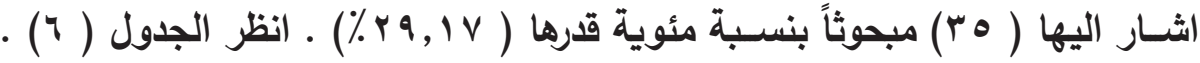
جـدول (7) يبيـن معدل اسـتخدام المبحوثين للفيس بوك في اليوم الواحد

\begin{tabular}{|c|c|c|}
\hline النسبة المئوية ٪\% & التكرار & معدل الاستخدام \\
\hline$\%$ \% . & $\varepsilon \wedge$ & مرتان في اليوم \\
\hline$\% r \cdot, \wedge r$ & $r v$ & ثلاث مرات باليوم فأكثر \\
\hline$\% r q, 1 \vee$ & o & مرة في اليوم \\
\hline$\% 1 \ldots$ & ir. & المجموع \\
\hline
\end{tabular}

V- - vدة الاستخدام

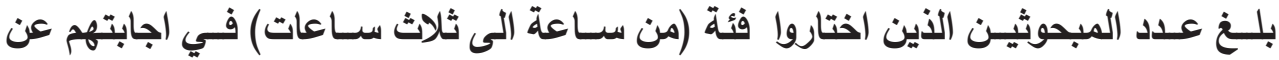

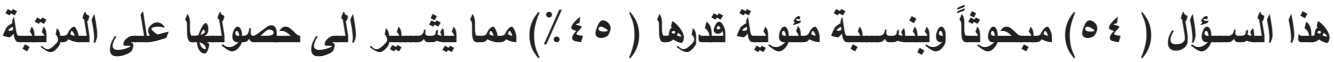

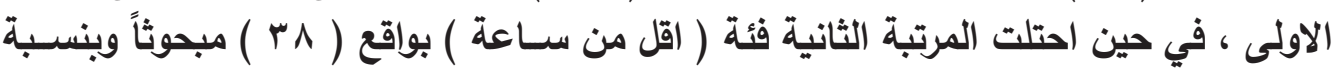

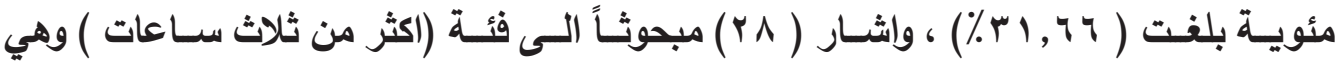

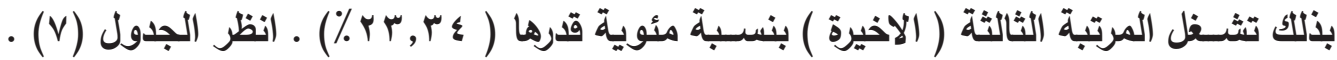
جـول (V) يبيـن توزيـع المــة التـي يسـتغرقها المبحوثيـن في اسـتخدامهم للفيس بوك

\begin{tabular}{|c|c|c|}
\hline النسبة المئوية \% & التكرار & مدة الاستخدام \\
\hline$\% \leqslant 0$ & $0 \leqslant$ & من ساعة الى ثُلاث ساعات \\
\hline צד, צי & rı & اقل من ساعة \\
\hline \% & rی & اكثر من ثلاث ساعات \\
\hline$\% 1 \ldots$ & ir. & المجموع \\
\hline
\end{tabular}




\section{^- فترات الاستخدام}

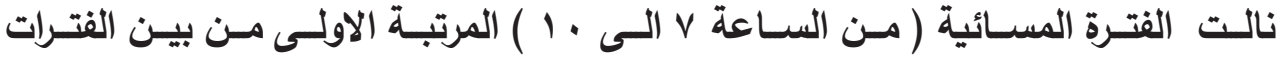

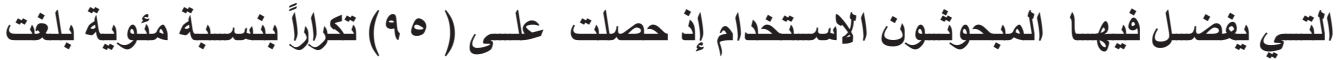

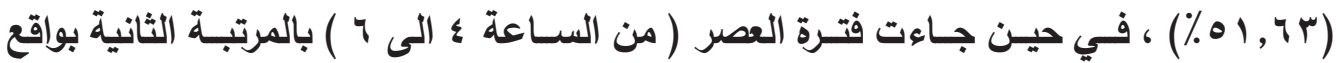

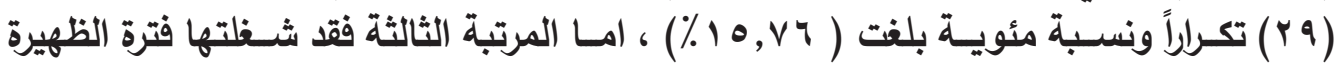

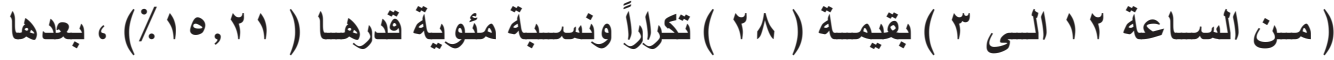

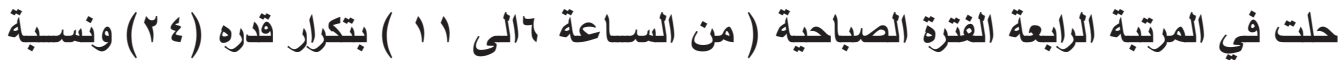

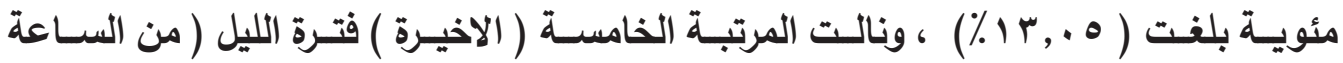

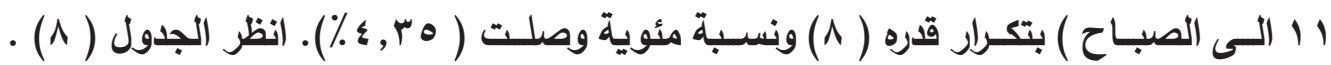
جـدول (^) يبيـن ترتيب الفتـرات التـي يفضـل فيهـا المبحوثيـن اسـتخدام الفيس بـوك

\begin{tabular}{|c|c|c|}
\hline النسبة المئوية \% & 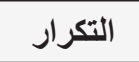 & الفترات التي يفضل فيها المبحوثين الاستخدام \\
\hline$\%$ & 90 & الفترة المسائية ( من الساعة V الى · 1 ) \\
\hline$\% 10, \vee_{4}$ & rq & فترة العصر ( من الساعة ؛ الى 7 ) \\
\hline$\%(0, Y 1$ & rA & فترة الظهيرة ( من الساعة ج ا الى ) \\
\hline$\% 1 r, .0$ & $r \leqslant$ & الفترة الصباحية ( من الساعة خالى ل 1 ) \\
\hline$\%$ \%, ro & $\wedge$ & فترة الليل ( من الساعة ل 1 الى الصباح ) \\
\hline$\% 1 \ldots$ & $(1+x+x) \backslash 1 \varepsilon$ & 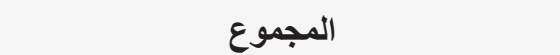 \\
\hline
\end{tabular}

\section{9- اماكن الاستخدام}

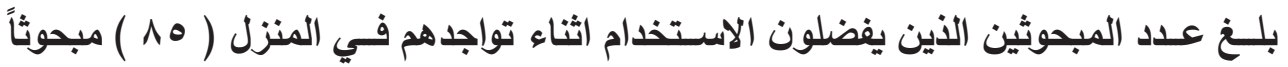

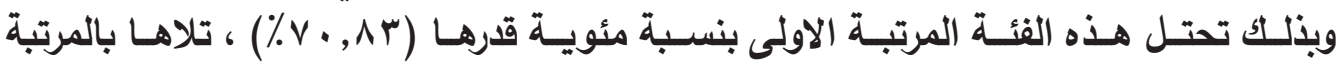

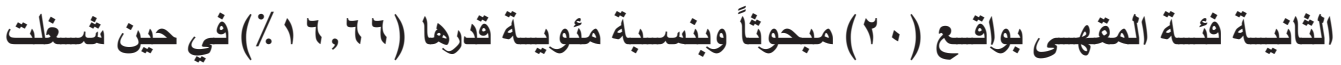

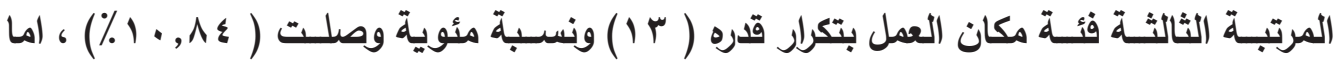

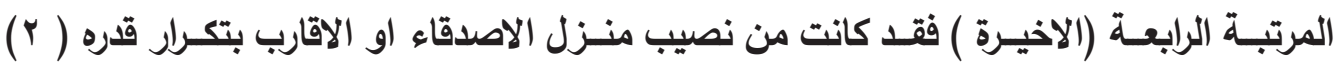

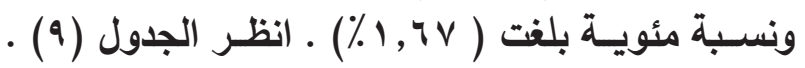


جدول ( 9) يبين تسلسل الاماكن التي يفضل المبحوثون التواجد فيها اثناء استخدامهم للفيس بوك

\begin{tabular}{|c|c|c|}
\hline النسبة المئوية \% & 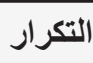 & الاماكن التي يفضل المبحوثين التواجد فيها اثثاء الاستخدام \\
\hline$\% \cdot \cdot, \wedge r$ & 10 & 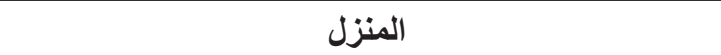 \\
\hline \% & $r$. & المقهي \\
\hline$\% 1, \wedge \leq$ & $1 \%$ & مكان العمل \\
\hline$\% 1,7 \vee$ & r & منزل الاصدقاء او الاقارب \\
\hline$\% 1 \ldots$ & ir. & المجموع \\
\hline
\end{tabular}

\section{. 1 - الاجهزة التي يفضل المبحوثون استخدامها}

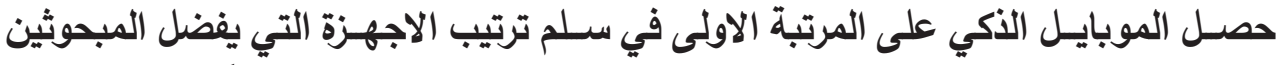

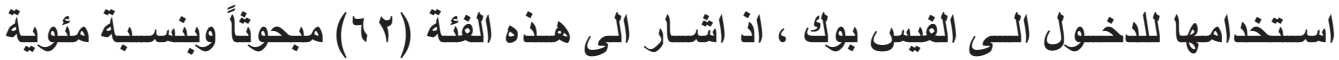

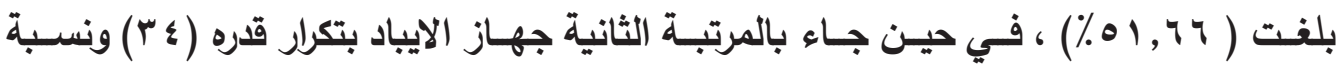

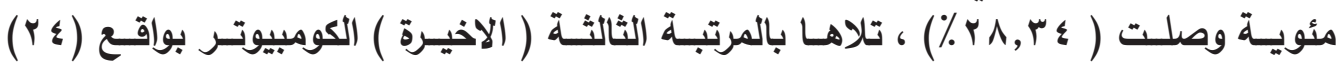

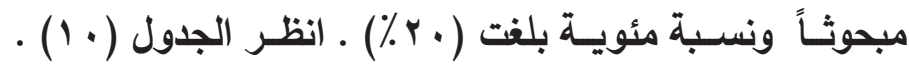
جدول ( • 1) يبين ترتيب الاجهزة التي يفضل المبحوثين استخدامها عند الاخول للفيس بوك

\begin{tabular}{|c|c|c|}
\hline النسبة المئوية ٪ & التكرار & الاجهزة المفضلة للاستخدام \\
\hline$\% 01,79$ & $\pi$ & الموبايل الذكي \\
\hline$\%$ \%, r $\varepsilon$ & $r \varepsilon$ & الآيباد \\
\hline$\% r$ & $r \varepsilon$ & الكومبيوتر \\
\hline$\% 1 \ldots$ & ir. & 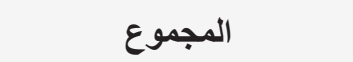 \\
\hline
\end{tabular}

\section{1ا- الاسم المفضل}

بلـنغ عـد المبحوثيـن الذين يفضلون اسـتخدام اســهم الحقيقي عند التسـجيل في الفيس

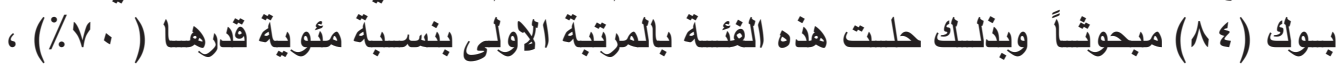

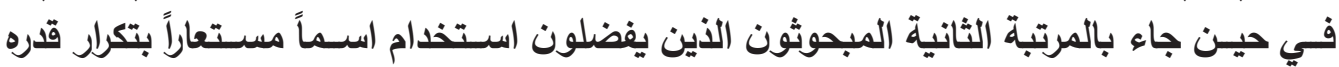

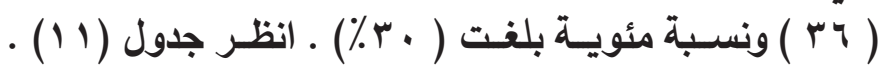


جدول (1 1 ) يبين ترتيب الاسماء التي يفضل المبحوثين استخدامه على صفحة الفيس بوك

\begin{tabular}{|c|c|c|}
\hline النسبة المئوية ٪ & التكرار & 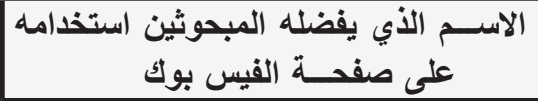 \\
\hline$\%$. & $\Lambda \varepsilon$ & الاسم الحقيقي \\
\hline$\% r$ & $r q$ & الاسم المستعار \\
\hline$\% 1 \ldots$ & ir. & المجموع \\
\hline
\end{tabular}

\section{r ا- الانشطة التي يقوم بها المبحوثون}

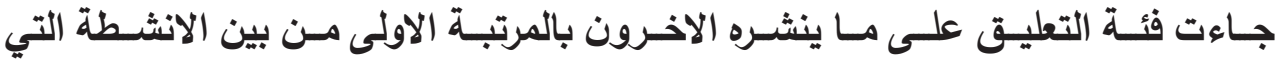

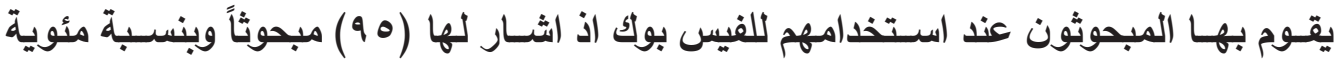

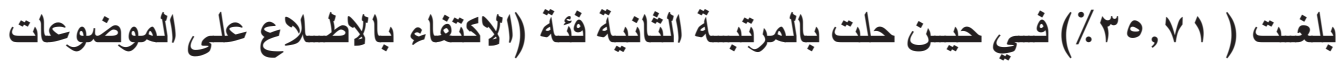

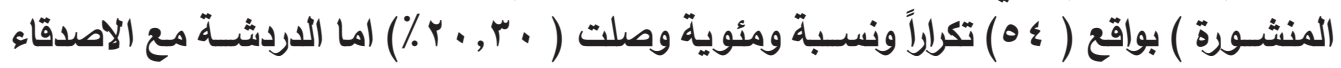

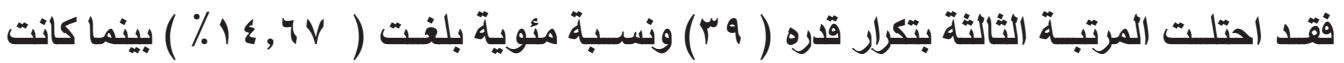

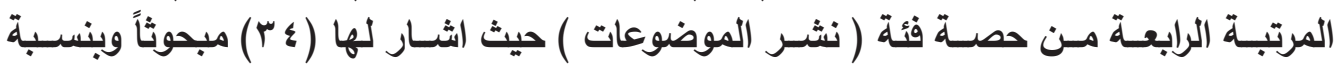

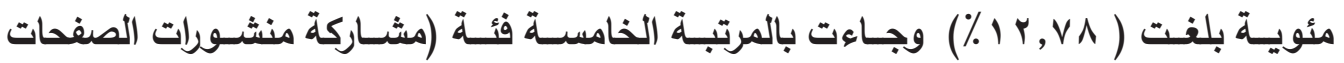

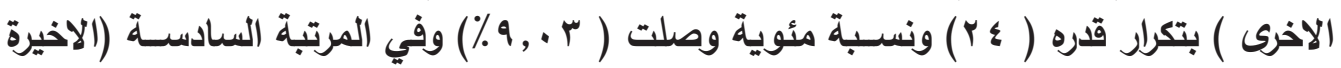

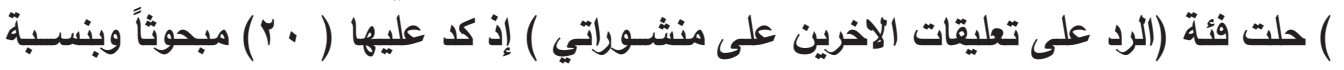

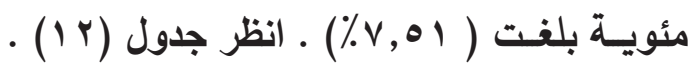
جدول (r I ) يبين تسلسـل الانثـطة التي يقوم بها المبحوثين عند اسـتخدامهم للفيس بوك

\begin{tabular}{|c|c|c|}
\hline 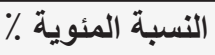 & 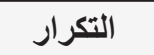 & الانشطة التي يقوم بها المبحوثين عذد استخدامهم للفيس بوك \\
\hline$\%$ \%, VI & 90 & التعليق على ما ينشره الاخرون \\
\hline$\% r \cdot, r \cdot$ & • & الاكتفاء بالاطلاع على الموضوعات المنشورة \\
\hline$\% 1 \leqslant, 7 \vee$ & $r q$ & الدردشة مع الاصدقاء \\
\hline$\%$ \% r,vA & ז & 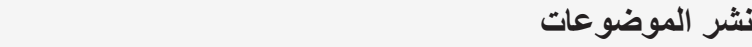 \\
\hline$\% 9, \cdot r$ & $r \varepsilon$ & مشاركة منشورات الصفحات الاخرى \\
\hline$\%, 01$ & r. & الرد على تعليقات الاخرين على منشوراتي \\
\hline$\% 1 \ldots$ & ()$\left.^{* * * * * *}\right)$ หฯฯ & المجموع - الموع \\
\hline
\end{tabular}




\section{المحور الثالث : دوافع الاستخدام}

1- تساعدني على التعبير عن آرائي في القضايا المختلفة كشفت اجابات المبحوثين بشأن هذا الدافع ما يأتي أ. احياناً : اشار الى ذلك (V^) مبحوثاً وبنسبة مئوية قدرها ( ه ؟\%).

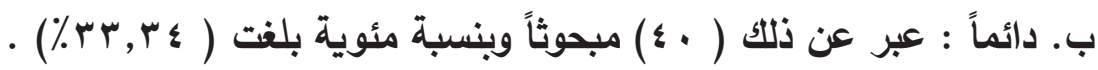
ت. ابداً : اكد على ذلك ( r) من المبحوثين وبنسبة مئوية وصلت ( צ ؟, 1\%) . ץ- تمكنني من التواصل ومتابعة اخبار الاصدقاء والاقارب كانت اجابات المبحوثين عن هذا الدافع كما يأتي :

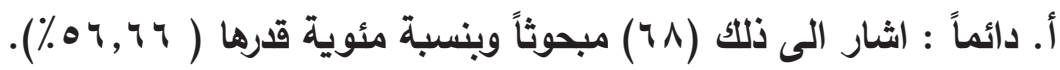

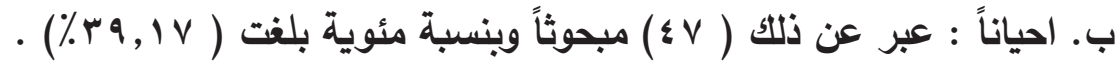

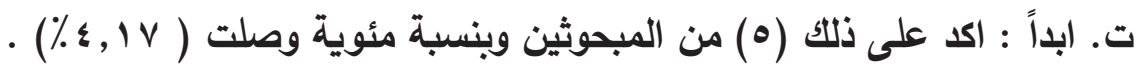
r- تساعدني على التخلص من الملل والقضاء على وقت الفراغ : بينت اجابات المبحوثين بشأن هذا الدافع ما يأتي :

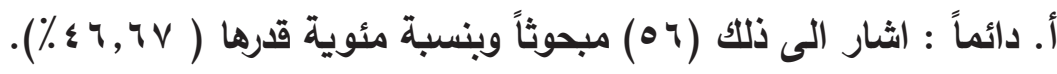

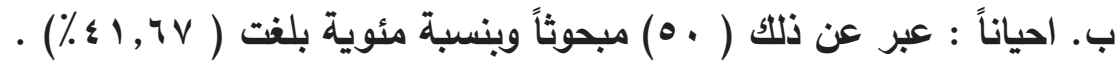
ت. ابداً : اكد على ذلك ( \& 1) من المبحوثين وبنسبة مئوية وصلت ( צج, 11 1\%) . ء- تتيح لي الاطلاع على الاحداث الجارية : كانت اجابات المبحوثين عن هذا الدافع كما يلي : أ. دائماً : اشار الى ذلك (ه 9) مبحوثاً وبنسبة مئوية قدرها ( . ^\%).

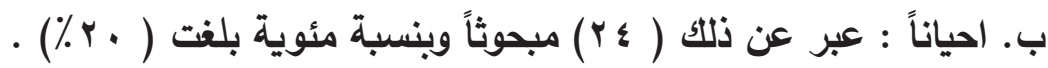
ت. ابداً : لم يؤكد اي من المبحوثين على ذلك ولم تحصل على اي تكرار.

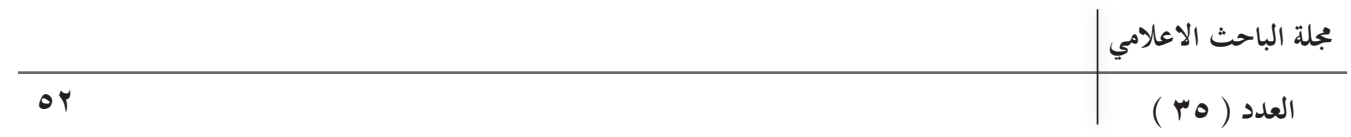


ه- توفر لي فرصة للترفيه والتسلية : بينت اجابات المبحوثين حول هذا الدافع ما يأتي :

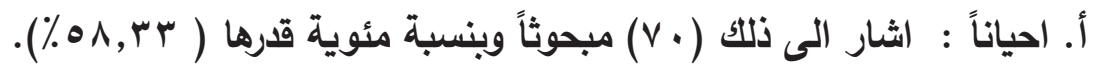

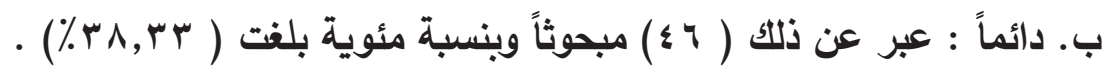

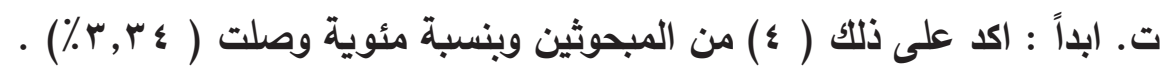
צ- تزيد من معارفي ومواكبتي للمستجدات في المجالات المختلفة :

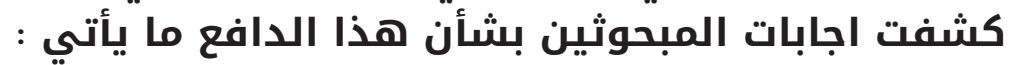

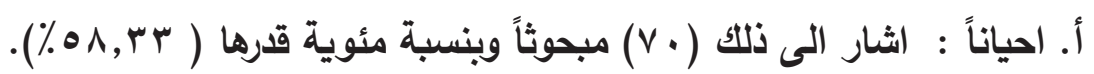

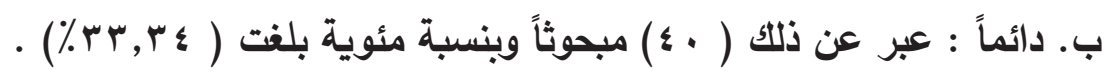

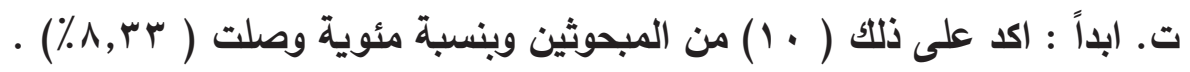
v- تمكنني من اقامة علاقات اجتماعية جديدة : بينت اجابات المبحوثين بشأن هذا الدافع ما مأنئن

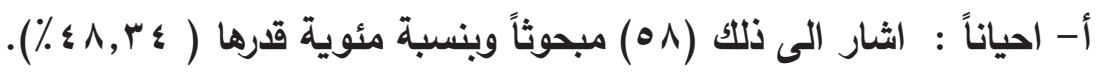

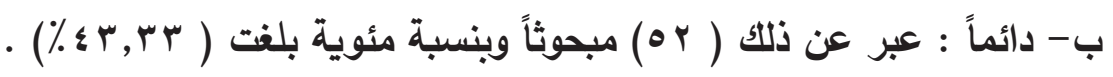

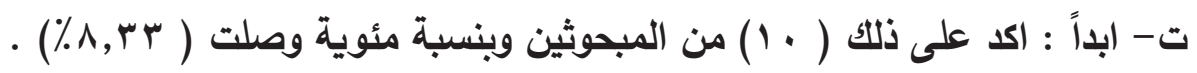
^- تتيح لي فرصة الترويج عن السلع والخدمات : التين كانت اجابات المبحوثين عن هذا الدافع كما يأتي:

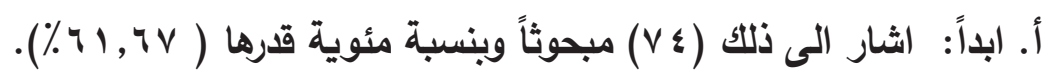

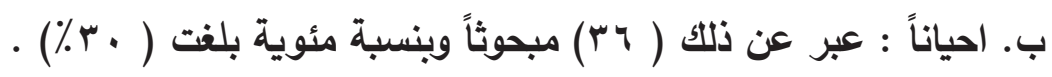

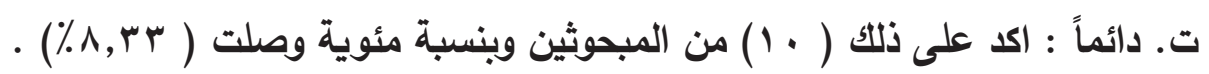

9- تساعدني على الهروب من مشكلات الحياة اليومية : كشفت اجابات المبحوثين بشأن هذا الدافع ما يأتي :

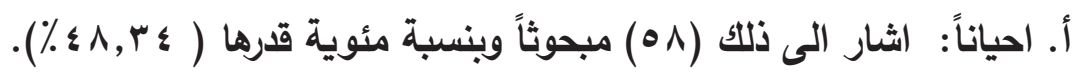

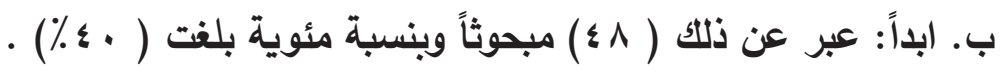

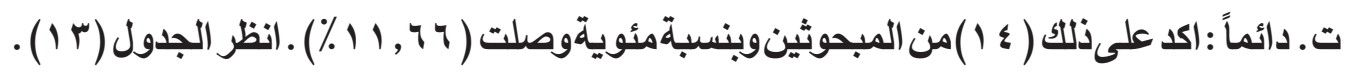

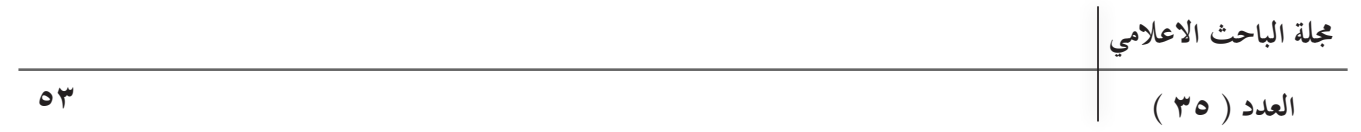


جدول (r ا ) يبين اجابات المبحوثين بثـأن دوافع اسـتخدامهم للفيس بوك

\begin{tabular}{|c|c|c|c|c|c|c|c|c|}
\hline \multicolumn{2}{|c|}{ المجموع } & \multicolumn{2}{|l|}{ ابداً } & \multicolumn{2}{|c|}{ 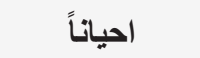 } & \multicolumn{2}{|c|}{ 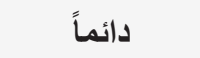 } & \multirow[b]{2}{*}{ دوافع الاستخدام } \\
\hline$\therefore$ & $\check{\underline{E}}$ & $\therefore$ & $\underline{\underline{E}}$ & $\therefore$ & $\underline{\underline{E}}$ & $\therefore$ & $\underline{E}$ & \\
\hline$\% 1 \ldots$ & Ir. & $\% 1,74$ & r & $\% 40$ & $\vee \wedge$ & $\% r r, r \varepsilon$ & $\varepsilon$. & تالقضاعاني على المختفة التعبير عن آرائي في \\
\hline$\% 1 \ldots$ & ir. & $\%$ \%, $\vee V$ & 0 & $\%$ \%, IV & $\leqslant v$ & \%०४, & 71 & تاصكنتي من التواصل والارب ومتابعة اخبار \\
\hline$\% 1 \ldots$ & ir. & $\% 11,47$ & $1 \leqslant$ & $\% \leqslant 1,4 \vee$ & 0. & \% & 09 & والقضاعاءني على وقت التظلص من الملل \\
\hline$\% 1 \ldots$ & ir. & $\%$ & . & $\%$. & $r \leqslant$ & $\%$. & 99 & جــــــي الاطـلاع علـى الاحـــاث \\
\hline$\% 1 \ldots$ & ir. & $\% r, r \leq$ & $\varepsilon$ & $\% \Delta \wedge, r r$ & $v$. & $\% \mu \wedge, r \mu$ & $\leq 7$ & توفر لي فرصة الترفيه والتسلية \\
\hline$\% 1 \ldots$ & Ir. & $\% \Lambda, r \mu$ & 1. & $\% \Delta \wedge, r \mu$ & $v$. & \& & $\varepsilon$. & تلزيد من معارفي ومواكبتي ألمختلفة \\
\hline$\% 1 \ldots$ & Ir. & $\% \wedge, r r$ & 1. & $\% \leqslant \wedge, \Gamma \leqslant$ & $0 \wedge$ & $\% \varepsilon r, \mu r$ & Or & تمكنني من اقامة علاقات اجتماعية \\
\hline$\% 1 \ldots$ & ir. & \% & $V \varepsilon$ & $\%$. & rq & \%, & 1. & والخّماتي فرصة الترويج عن السلع \\
\hline$\% 1 \ldots$ & ir. & $\%$ \%。 & $\varepsilon \wedge$ & $\% \varepsilon \wedge, \Gamma \leqslant$ & 01 & $\% 11,74$ & $1 \leqslant$ & ل إل الهروب من مشكلات \\
\hline
\end{tabular}




\section{المحور الرابع : الاشباعات المتحققة}

1- اوجد لي مساحة للتعبير عن آرائي بحرية : كشفت مواقف المبحوثين بشأن هذه الفقرة ما يأتي :

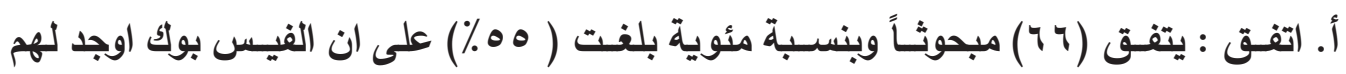

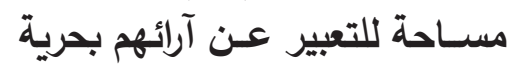

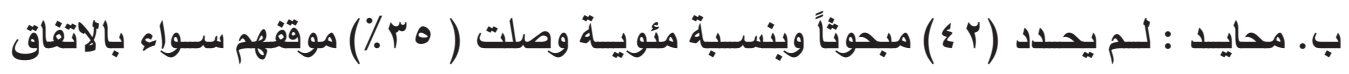

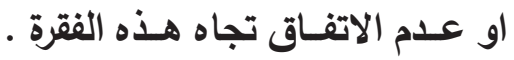

ت. لا اتفق : لم يتفق (Y I) مبحوثاً وبنسبة مئوية بلغت ( • (\%) على ذلك . r- وفر لي جواً تواصلياً مع اصدقائي واقربائي : جاءت مواقف المبحوثين بشأن هذه الفقرة كما يأتي:

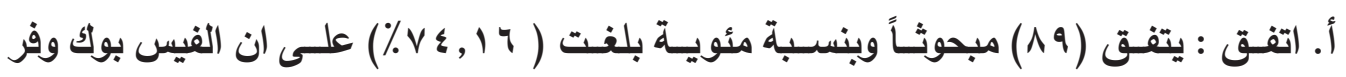

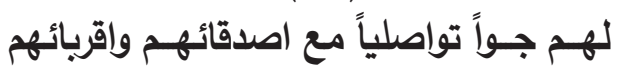

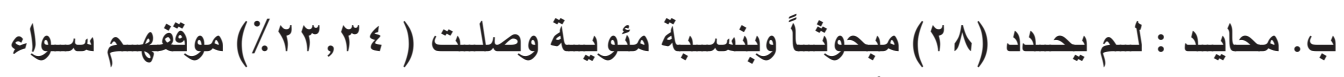

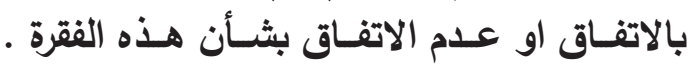
ت. لا اتفق : لم يتفق (ץ) من المبحوثين وبنسبة مئوية بلغت ( ه, ؟\%) على ذلك . r. قلل من شعوري بالملل والفراغ : حدد المبحوثين موقفهم من هذه الفقرة بما يأتي :

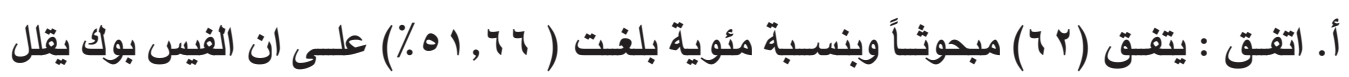

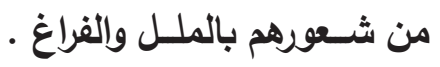

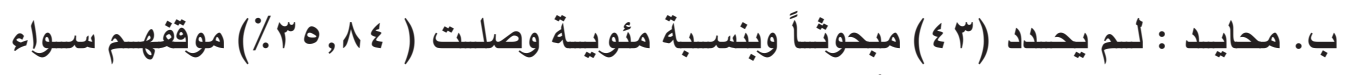

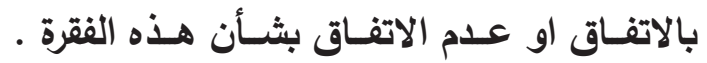

ت. لا اتفق : لم يتفق (0 1 ) من المبحوثين وبنسبة مئوية بلغت ( 0, ب ٪) على ذلك .

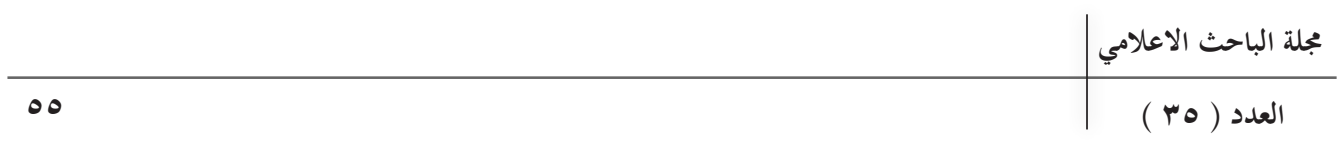


؟ - ساعدني على تكوين علاقات اجتماعية جديدة : كشفت مواقف المبحوثين بشأن هذه الفقرة ما يأتي :

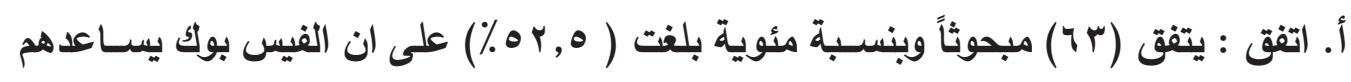

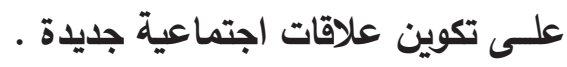

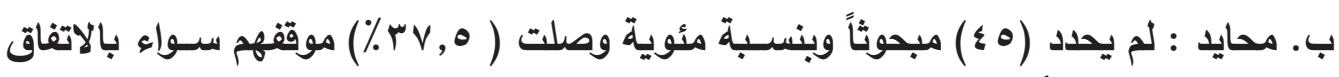

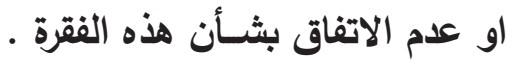

ت. لا اتفق : لم يتفق (Y I) من المبحوثين وبنسبة مئوية بلغت ( 1\%) على ذلك . ه- جعلني مطلعاً على ما يدور من احداث : جاءت مواقف المبحوثين بشأن هذه الفقرة كما يأتي :

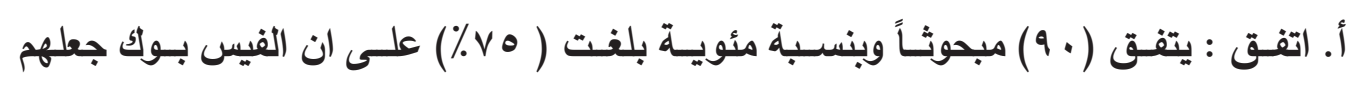

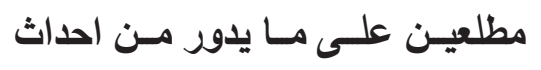

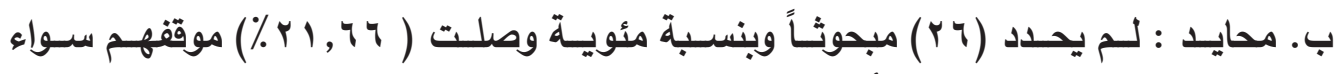

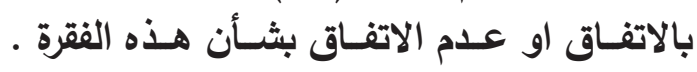

ت. لا اتفق : لم يتفق (؛) من المبحوثين وبنسبة مئوية بلغت ( ع ؟,ץ\%) على ذلك .

צ- اسهم في مواكبتي للمستحدثات في المجالات المختلفة : كشفت مواقف المبحوثين بشأن هذه الفقرة ما يأتي :

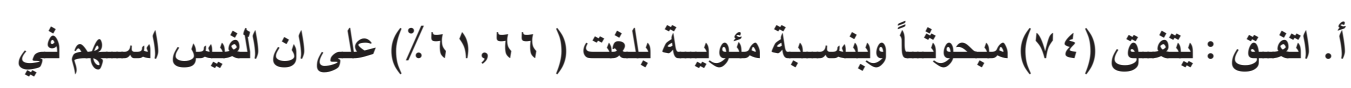

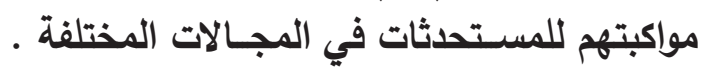

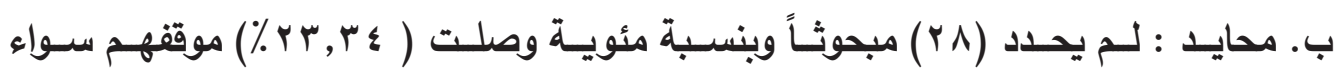

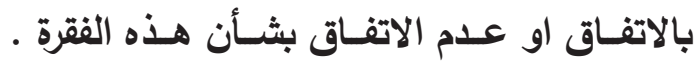
ت. لا اتفق : لم يتفق (1 1 ) من المبحوثين وبنسبة مئوية بلغت ( ه 1\%) على ذلك . \begin{tabular}{c|c} 
& مجلة الباحث الاعلامي \\
\hline 04 & العدد (r) )
\end{tabular} 
v- تحقق لدي نوعاً من الاسترخاء والشعور بالمتعة : حدد المبحوثين موقفهم من هذه الفقرة بما يأتي:

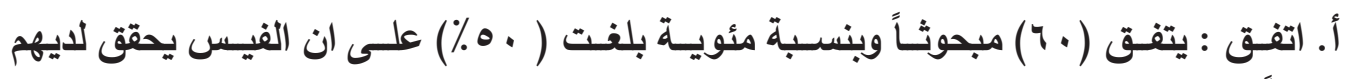
نوعـاً من الاستـرخاء والثــور بالمتعة . .

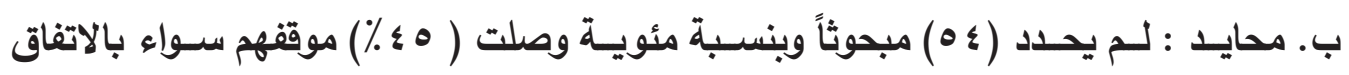
او عـدم الاتفاق بثــأن هـذه الفقرة .

ت. لا اتفق : لم يتفق (†) من المبحوثين وبنسبة مئوية بلغت ( ه\%) على ذلك .

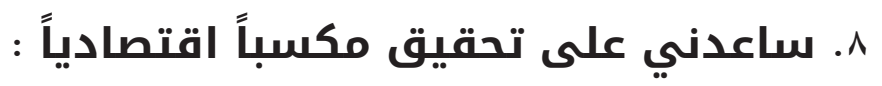

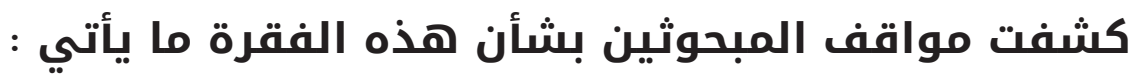

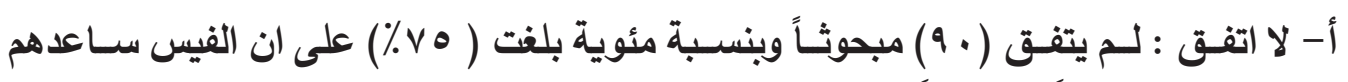
على تحقيق مكسباً اقتصادياً . ب- اتفق : اتفق (1 1) مبحوثاً وبنسبة مئوية وصلت ( ع ب, ب 1\%) على ذلك .

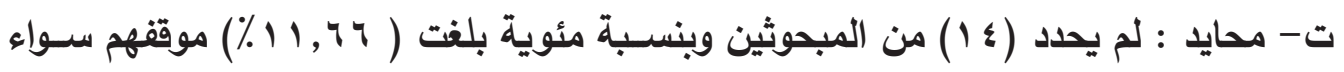

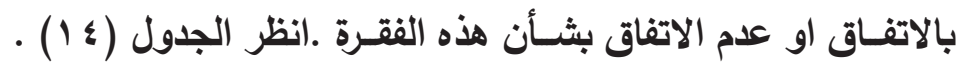

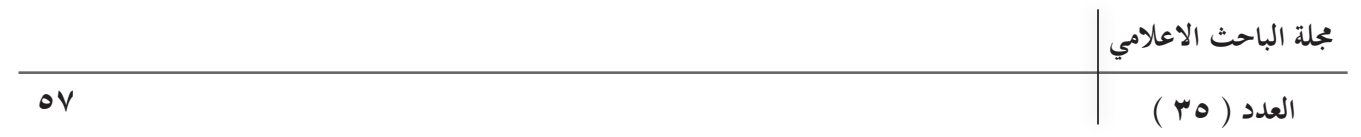


جـول ( ع ا ) يبين مدى اتفاق المبحوثين مـع الاثـباعات المتحققة

\begin{tabular}{|c|c|c|c|c|c|c|c|c|}
\hline \multicolumn{2}{|c|}{ المجموع } & \multicolumn{2}{|c|}{ لا لا اتفق } & \multicolumn{2}{|c|}{ 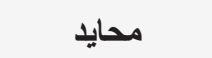 } & \multicolumn{2}{|c|}{ اتقق } & \multirow[b]{2}{*}{ الإشـاعات المتحققة } \\
\hline$\therefore$ & $\underline{E}$ & $\therefore$ & $\underline{E}$ & $\therefore$ & $\underline{E}$ & $\therefore$ & $\underline{\underline{E}}$ & \\
\hline$\% 1 \ldots$ & $k r$. & $\% 1$. & Ir & $\%$ ro & $\varepsilon r$ & $\% 00$ & 74 & آرائي بحرية ليساحة للتعبير عن \\
\hline$\% 1 \ldots$ & $1 \%$. & $\%$ \%,० & $r$ & ( & rs & $\% \vee \leqslant, 17$ & $\wedge q$ & وفر لي جواً تو اصلياً مع \\
\hline$\% 1 \ldots$ & ir. & $\%$ ir,o & 10 & $\% r \Delta, \wedge \varepsilon$ & $\varepsilon$ & $\% 01,74$ & Tr & قلل من شعوري بالملل والفراغ \\
\hline$\% 1 \ldots$ & 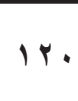 & $\% 1$. & Ir & $\% r v, 0$ & $\leq 0$ & $\%$ ०४, ० & זי & اجتماعيّية جلى تكوين علاقات \\
\hline$\% 1 \ldots$ & $k r$. & $\%$ & $\varepsilon$ & \% & T & $\%$ vo & 9. & جعاثي مطلعاً على ما يدور من \\
\hline$\% 1 \ldots$ & $k r$. & $\% 10$ & 11 & \% & Y & די, & $V \varepsilon$ & 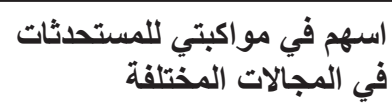 \\
\hline$\% 1 \ldots$ & $k r$. & $\%$ & 7 & $\% \leqslant 0$ & 0 \& & $\%$. & 7. & و تحقق لاي نوعاً من الاسترخاء \\
\hline$\% 1 \ldots$ & ir. & $\%$. 0 & 9. & $\% 11,74$ & $1 \varepsilon$ & \% & 17 & اقتصادياً على تحقيق مكسباً \\
\hline
\end{tabular}




\section{النتائج العامة للبحث}

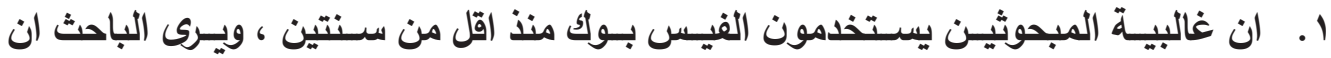

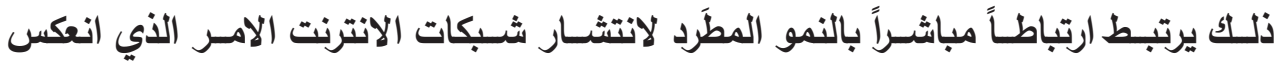

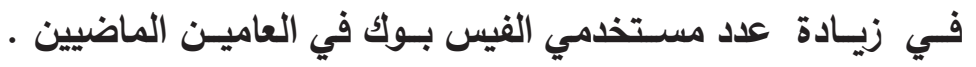
r. ـ يسـتخدم معظم المبحوثين الفيس بوك مرتان باليوم ويسـتغرق غالبيتهم مدة من ســاعة

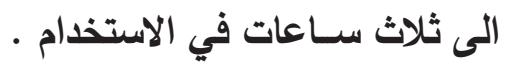

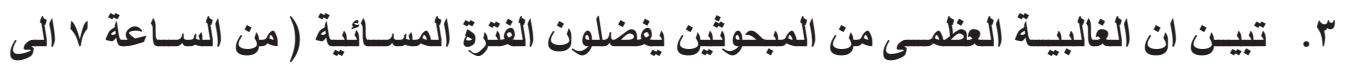

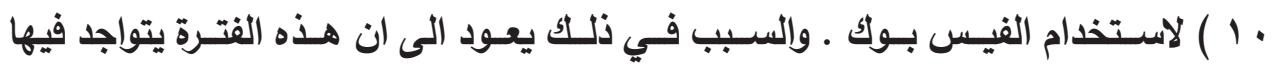

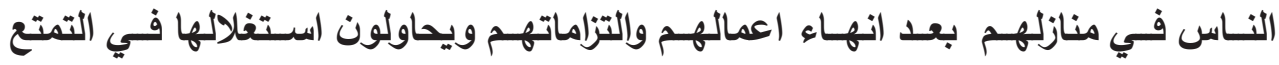

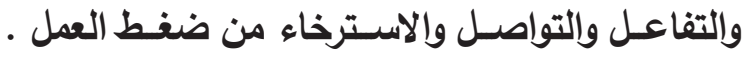

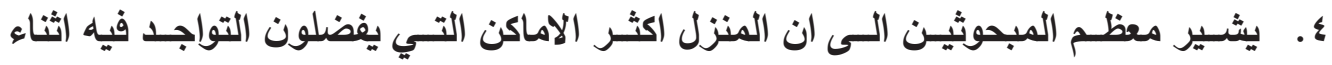

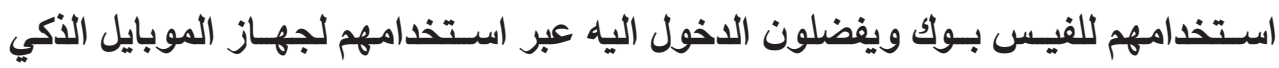

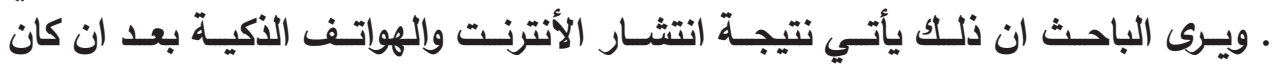

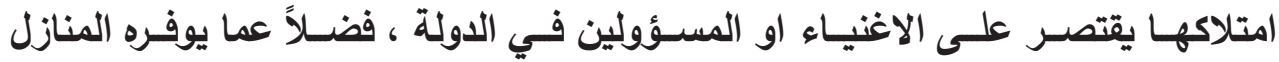

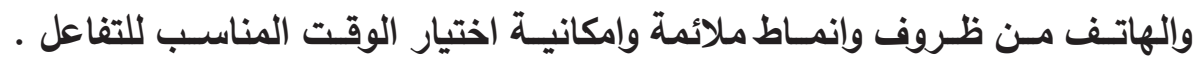

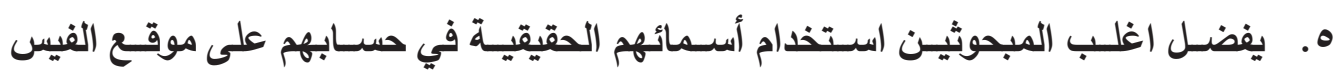

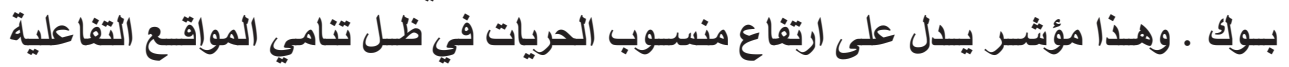

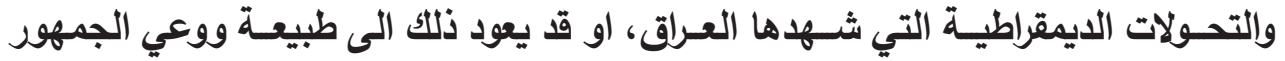

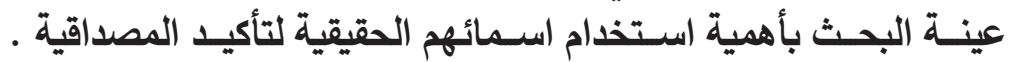

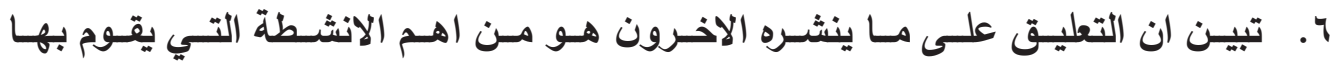

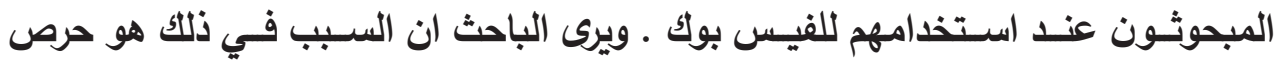

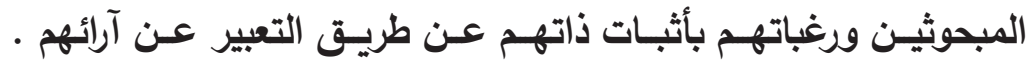

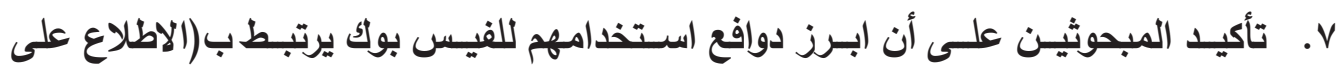

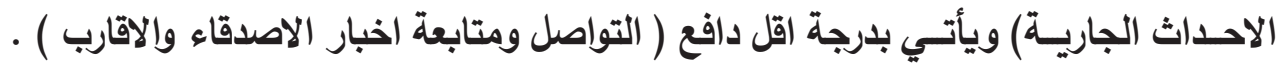
^. اتفق المبحوثين على أن ابرز الاشباعات المتحققة بفعل استخدامهم للفيس بوك هو ( جعلهم مطلعيـن على مــا يدور من احداث ) وحقق لهم ( جواً تواصليـاً مع الاصدقاء والاقارب ) . 


\section{المصادر والهوامش}

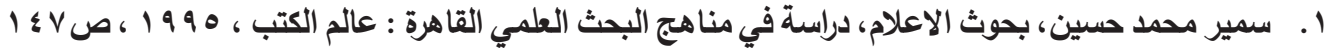

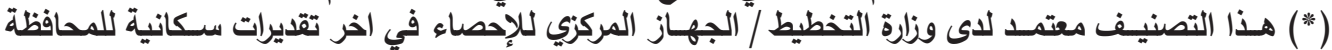

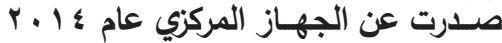

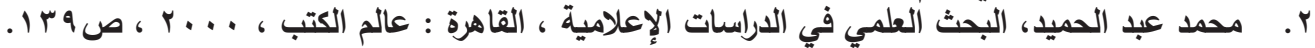

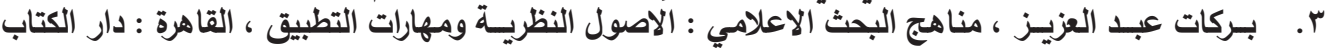

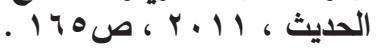

(أ. (سماء المحكمين الخبراء

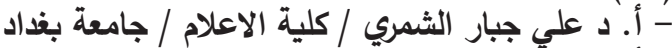

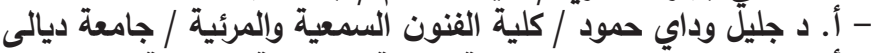

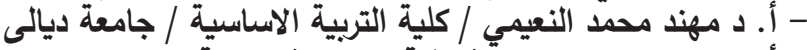

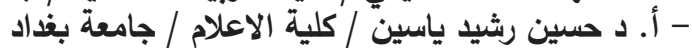

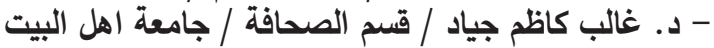

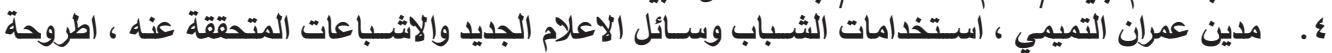

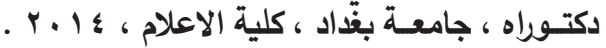

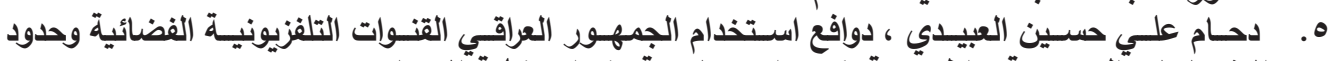

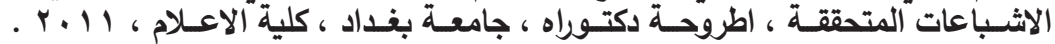

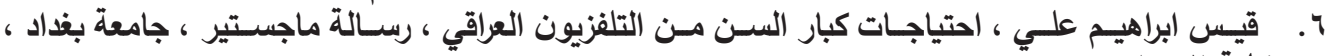

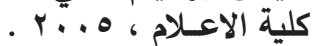

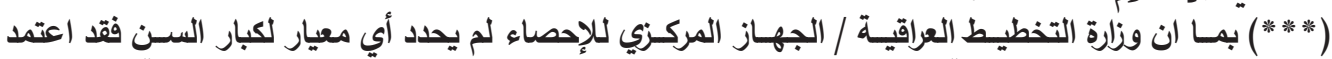

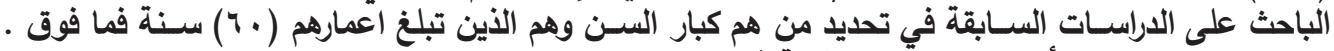

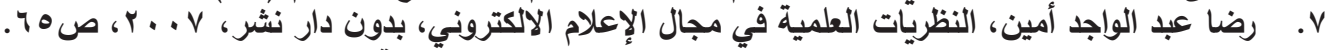

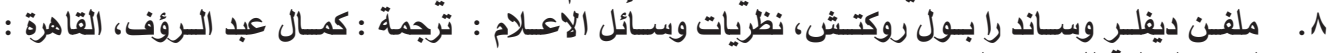

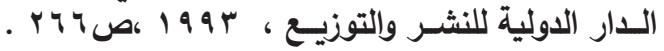

Abd El- Basit Ahmed Hashem, UsEs and Gratiflctions of online advertising . . a comparative study between germany and egept, degree of Doctor, Mass

I Y.P.Y. 1 · communications Techndogical university of IImenau

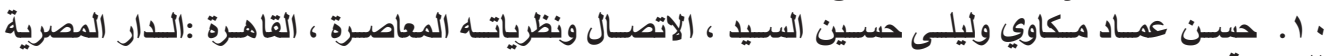

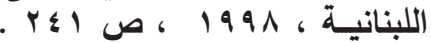

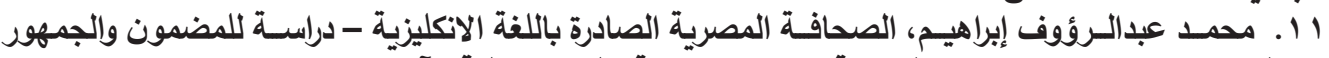

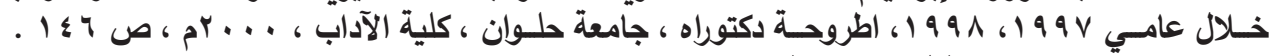

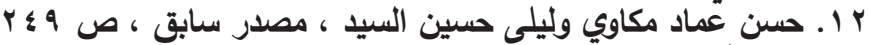

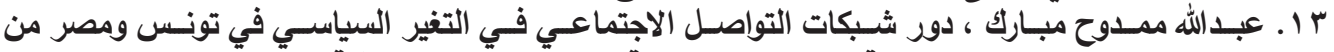

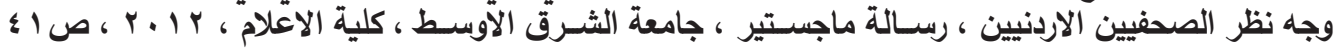

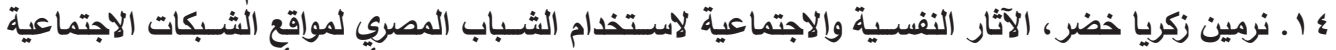

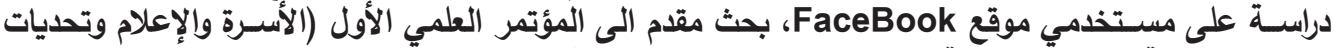

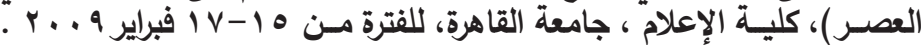

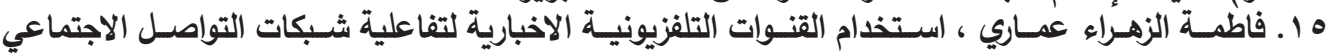

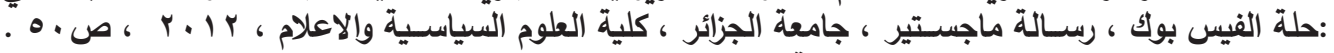

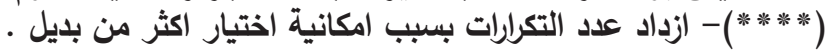

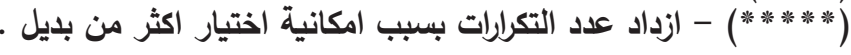

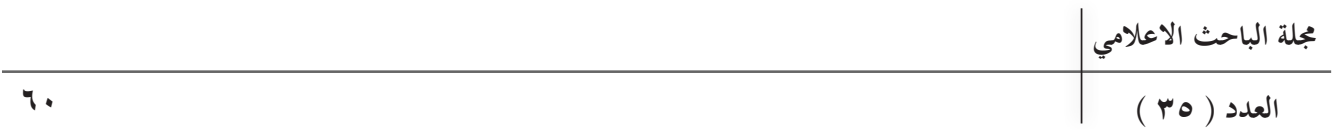

